Yönelik Panel Veri Analizi, BMIJ, (2020), 8(4): 764-796, doi:

Ülkelerine Yönelik Panel Veri
http://dx.doi.org/10.15295/bmij.v8i4.1577

\title{
SOSYAL AMAÇLI TRANSFER HARCAMALARININ GELİR DAĞILIMINA ETKİSİ: OECD ÜLKELERINNE YÖNELİK PANEL VERİ
}

ANALİí

Mehmet Ali POLAT 1

$\ddot{O Z Z}$

\section{Anahtar Kelimeler:}

Transfer Ödemeleri,

Gelir Dağılımı,

Panel Veri Analizi Yöntemi,

GINI Katsayisı

JEL Kodlari:

E62,

I10,

D31,

C33
Received Date (Başvuru Tarihi):

Accepted Date (Kabul Tarihi):

Published Date (Yayın Tarihi):
$23 / 07 / 2020$

$5 / 11 / 2020$

$10 / 12 / 2020$

Bu çalı̧̧mada transfer ödemelerinin gelir dağılımına etkisi, 36 OECD ülkesinin 1996-2018 dönemi verileri kullanularak, panel veri analizi yöntemiyle incelenmiştir. Çalışmada bağımlı değişken olarak; GINI katsayısı, bağımsız değişken olarak hane halkına yönelik transfer ödemelerinin milli gelire oran verileri kullanılmıştır. Ayrıca ekonomik büyüme oranı, nüfus artış hızı 2008 küresel ekonomik krizini temsil eden kukla değişken de analize dâhil edilmiştir. Çalışmada yer verilen serilerin durağanlikları LLC, IPS, Fisher $A D F$ ve Fisher PP panel birim kök testleri ile sinanmış ve serilerin düzeyde durağan olduklan görülmüştür. Panel regresyon analizinde hangi yöntemin kullanılacağının belirlenmesine yönelik olarak Hausman (1978) testi yapılmıştır. Yapılan panel regresyon analizleri sonucunda; OECD ülkelerinde, 1996- 2018 döneminde hanehalkına yönelik gerçekleştirilen transfer ödemeleri ve ekonomik büyümenin gelir dağılımı eşitsizliğini azalttığ tespit edilmiştir. Seriler arasında nedensellik ilişkileri; Dumitrescu ve Hurlin (2012) panel nedensellik testi ile incelenmiş ve transfer ödemeleri ve nüfus artış hızı ile gelir dağılımı eşitsizliği arasında ve transfer ödemeleri ile nüfus artış hızı arasında karşılıkh nedensellik iliş̧kileri bulunmuş̧tur. Ayrıca gelir dağılım eşitsizliğinden ekonomik büyümeye, ekonomik büyümeden transfer ödemeleri ve nüfus artış hızına doğru da tek yönlü nedensellik ilişkileri belirlenmiştir.

Keywords: Transfer Payments Income Distribution Panel Data Analysis Method

GINI Coefficient

JEL Codes:

E62

I10

D31

C33

\footnotetext{
${ }^{1}$ Dr. Öğr. Üyesi, Malatya Turgut Özal Üniversitesi, İ.Y.B.F., mehmet.polat@ozal.edu.tr, https://orcid.org/0000-0001-9239-8228
} 


\section{EXTENDED ABSTRACT}

\section{THE IMPACTS OF TRANSFER PAYMENTS FOR SOCIAL PURPOSES ON INCOME DISTRIBUTION: PANEL DATA ANALYSIS FOR OECD COUNTRIES}

\section{LITERATURE SURVEY}

\subsection{RESEARCH SUBJECT}

In this study, the effect of transfer payments on income distribution was examined by panel data analysis method, using data from 36 OECD countries for 1996-2018 period. In the study; GINI coefficient was used as the dependent variable, and the data for the ratio of household transfer payments to national income was as the independent variable. As a result of the panel regression analysis; it was determined that in OECD countries, transfer payments to households and economic growth reduced income inequality in 1996-2018 period.

Based on the findings of Gustafsson and Johansson (1999), Li et al. (2000), Keane and Prasad (2002), Sylwester (2002), Schwabish et al. (2004), Huber et al. (2004), Afonso et al. (2010), Niehues (2010), Hazman (2011), Holzner (2011), Caminada et al. (2012), Wang et al. (2012), Woo et al. (2013), MartínezVázquez et al. (2014), İlgün (2015), D’ Agostino et al. (2016), Cimoli et al. (2017), Eroğlu et al. (2017), Ürper (2018), Kozuharov and Petkovski (2018), Yardımcığlu and Yayla (2020); It can be stated that the transfer payments made by countries to their citizens have a decreasing effect on the income distribution imbalance. Therefore, it would be beneficial for countries to continue such aids within their means.

\subsection{RESEARCH PURPOSE AND IMPORTANCE}

The study aimed to examine the effect of social transfer expenditures on income distribution. The result that the transfer payments to households reduce income distribution inequality has made the study necessary in terms of guiding government policies.

\subsection{CONTRIBUTION of the PAPER to the LITERATURE}

It is thought that the study using data from 36 OECD countries will make a significant contribution to the literature by the finding that transfer payments to households will reduce income inequality.

\section{DESIGN AND METHOD}

\subsection{RESEARCH TYPE}

This study is a research paper, and a quantitative research design was adopted in the study.

\subsection{RESEARCH PROBLEMS}

In this study, the effect of transfer payments on income distribution was examined by panel data analysis method, using data from 36 OECD countries for 1996-2018 period.

\subsection{DATA COLLECTION METHOD}

The GINI coefficients are obtained from The Standardized World Income Inequality Database Version 8 prepared by Frederick (2019), which is in the Harvard University Data Bank. Transfer payments were gathered from OECD (2020b), economic growth and population data were from the World Bank (2020a, 2020b).

\subsection{QUANTITATIVE / QUALITATIVE ANALYSIS}

In this study, the effect of transfer payments on income distribution was examined by panel data analysis method, using data from 36 OECD countries for 1996-2018 period. In the study; GINI coefficient was used as the dependent variable, and the data for the ratio of household transfer payments to national income was as the independent variable. Also, economic growth rate, population growth rate, dummy variables representing the 2008 global economic crisis were included in the analysis. LLC tested the stationarity of the series included in the study, IPS, Fisher ADF and Fisher PP panel unit root tests and it was found that the series were stationary at level values. 
Since the countries in the analysis are spread over vast geography, and they do not have standard policies affecting the balance of income distribution, it is not expected that there will be crosssection dependencies between countries. Therefore, first-generation panel data analysis methods were preferred in the study. In this context, the stationarity of the series was tested by Levin, Lin and Chu (2002, LLC), Im, Pesaran and Shin (2003, IPS), Maddala and Wu (1999), Fisher ADF and Fisher PP panel unit root tests. The method to be used in the panel regression analysis was decided by the Hausman (1978) test. Causality relationships between the series were examined by Dumitrescu and Hurlin (2012) panel causality test.

\section{FINDINGS AND DISCUSSION}

\subsection{FINDINGS as a RESULT of ANALYSIS}

The existence and direction of causality relationships between series were examined by Dumitrescu and Hurlin (2012) panel causality test. As a result of this test; the mutual causality relationship was found between transfer payments and income distribution inequality in OECD countries. This relationship implies that when the income distribution imbalance in countries increases/decreases, transfer payments also increase/decrease. As a matter of fact, in the Covid-19 period, developed countries, especially the USA and Canada, gave unrequited money (made transfer payments) to their citizens whose monthly income was below a certain level. Two-way causality relationship between income inequality and population growth rate supports the premise that countries with high population growth rates also have high imbalances in income distribution. The mutual causality relationship between population growth rate and transfer payments also reminds the type of state aid of payments per child, especially in developed countries. The causality relationship from economic growth to transfer payments indicates that countries with higher income can provide more assistance to their citizens. The causality relationship from income inequality to economic growth suggests that when the income distribution imbalances in countries decreases, individuals get the return of their labor more quickly and, thus, they work more efficiently and contribute positively to the economic growth of their countries.

\section{CONCLUSION, RECOMMENDATION AND LIMITATIONS}

\subsection{RESULTS of the PAPER}

According to the findings obtained at the end of the study; in OECD countries, transfer payments to households in the 1996-2018 period reduced income inequality. This result is significant on the main question that our study focuses on. In that case; it would be beneficial for countries to continue to increase their transfer payments so that they can reduce the income imbalance among their citizens. Increases in economic growth have also reduced income inequality. This suggests that the income generated is shared equitably. Population growth, in addition to these, increased the income distribution imbalance. However, in the fixed effects model, it is seen that this effect is in the decreasing direction. For this reason, no decision could be reached on the effects of population growth. It has been determined that the 2008 Global Economic Crisis has a decreasing effect on the income distribution imbalance in the pooled model but at a statistically insignificant level.

\subsection{SUGGESTIONS BASED on RESULTS}

Based on the findings obtained from this paper, it can be stated that the transfer payments made by countries to their citizens have a decreasing effect on the income distribution imbalance; therefore it would be beneficial for countries to continue such aids within their means. However, at this point, the necessity of preventing some citizens from getting used to living with granted state aid without working and the importance of "teaching people how to fish instead of giving fish" and transforming them into working and producing individuals should not be overlooked. It should not be forgotten that such social assistance is always open to abuse, that people who are not really in need may try to benefit from these aids and this case may put the economy in a difficult situation as in Greece, and the public should take the necessary measures. It is of paramount importance that the income generated by economic growth is distributed equitably among all citizens. At this point, it is essential that states effectively fulfil their functions of regulating and controlling the salary and other personal rights of people working in the private sector. The abnormal increase in the population of the country with imbalanced immigration can reduce the welfare of the residents in the country. For this reason, it is beneficial for states to 
maintain their immigration policies in line with their economic strength and the number of people they can employ. 


\section{GİRIŞ̧}

Gelir dağılımı, bir ülkenin bireyleri tarafından üretilen mal ve hizmetlerin sağlamış olduğu toplam gelirin, ülkede yaşayan bireylere dağılım araçları aracılığıyla bölüşümünü ifade etmektedir. Bu paylaşımın adil bir şekilde olması, o ülkenin kalkınmışlık durumu açısından çok önemlidir. 1980 sonrası yıllarda, gelişmiş ülkelerde gelir dağılımında adaletsizliğin arttığı görülmektedir. Bu artışın temel nedenleri; ülke içinde bölgesel düzeyde yaşanan gelir eşitsizliklerinin artması, küreselleşmeyle birlikte vasıfsız emeğin ücretinin düşürülerek vasıflı işgücünün ücretinin artırılması, üretim ve faktör piyasalarında rekabeti artırıcı düzenlemeler, kırsal-kentsel bölgeler arasında yaşanan nüfus oranı farklılıkları ve tek çalışanlı aile tiplerinde yaşanan artışlar gibi olgulardır (Bastagli vd., 2012, s. 4).

Gelir dağılımındaki adaletsizlik, ekonomik büyümeye olan ters etkisinden dolayı istenmeyen bir durumdur. Sadece ekonomik hayatla sınırlı olmayan gelir dağllımındaki adaletsizlik; ülkelerin sosyal, toplumsal ve kültürel yapılarını da olumsuz yönde etkiler. Bu bağlamda, gelir dağılımının daha adaletli hale getirilmesi için hükümetler tarafından birçok kamu politikaları geliştirilmekte ve uygulanmaktadır. Kamu bütçesinden, hiçbir geliri olmayan veya düşük geliri olan tüketici kesime yönelik olarak yapılan sosyal amaçlı transfer harcamaları politikası birçok ülkede uygulanan en önemli olgulardan biridir (Alesina ve Rodrik, 1994; Persson ve Tabellini, 1994; Weede, 1997). Sosyal amaçlı transfer harcamaları, her ülkede kendine özgü nitelikleri ile ön plana çıkmakta ve gelirin yeniden dağılımı hususunda farklı kalemler ile etkide bulunmaktadır.

Çalışmanın ilk bölümünde; gelir dağılımının teorik çerçevesi oluşturularak gelir dağılımının ölçülmesi ve gelir dağılımın önemi konuları incelenmiştir. Bu bağlamda, GINI katsayısı kullanılarak ülkelerin gelir dağılımları karşılaştırılmıştır. İkinci bölümde; sosyal amaçlı transfer harcamalarının gelir dağılımına etkileri anlatılmıştır. Üçüncü bölümde; bazı OECD ülkelerinde sosyal amaçlı transfer harcamalarının GSYH'ye oranları alt başlıkları da göz önünde bulundurularak ayrıntılı bir şekilde incelenmiştir. Çalışmanın dördüncü bölümünde, transfer ödemelerinin gelir dağılımına etkisi, 36 OECD ülkesinin 1996-2018 dönemine ait 
verileri kullanılarak panel veri analizi yöntemiyle incelenmiştir. Çalışma, sonuç ve öneriler bölümüyle sonlandırılmıştır.

\section{GELİR DAĞILIMI İLE İLGİLI TEORİK ÇERÇEVE}

Gelir dağılımı eşitsizliği, belli bir orandaki nüfus diliminin milli gelirden aldığ1 pay ile aynı orandaki başka bir nüfus diliminin milli gelirden aldığı pay arasındaki farklılığı ifade etmektedir (DPT, 2020). Gelir dağılımının ölçülmesi; bir ülkede yaşanan ekonomik büyüme neticesinde artan milli gelirin yeniden dağılımı konusunda devletin, kendi politikalarını belirleyebilmesi açısından çok önemlidir (Çalışkan, 2010, s. 97). Bu bağlamda, gelirin yeniden dağıtılması, ülkelerin sosyal, ekonomik ve siyasal yapısını da değiştirebilmektedir. Literatürde, gelir dağılımını tespit edebilmek için ABD'li iktisatçı Max O. Lorenz tarafından geliştirilen Lorenz eğrisi ile İtalyan istatistikçi Corrado Gini tarafından geliştirilen Gini katsayısı ön plana çıkmaktadır. Şekil 1'de, gelir dağılımı eşitsizliğinin hesaplanabilmesi için ülkedeki nüfusun yüzde kaçının milli gelirin yüzde kaçını ele geçirdiğini belirten Lorenz eğrisi gösterilmiştir.

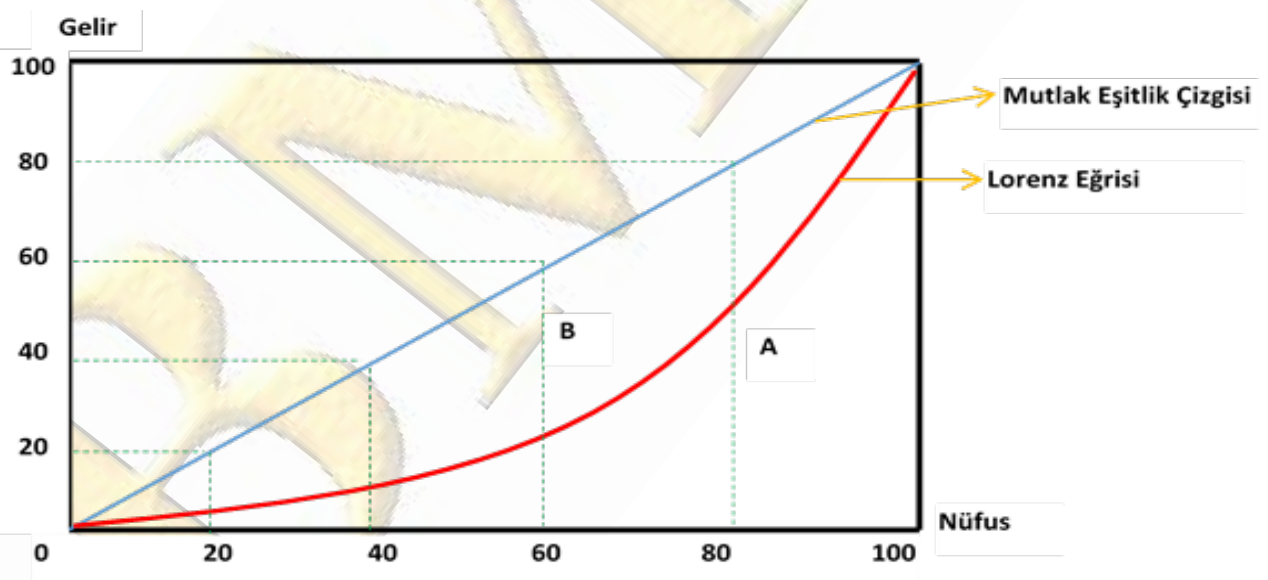

Şekil 1. Lorenz Eğrisi

Şekil 1'de görüldüğü üzere; dikey eksende gelir değişkeni, yatay eksende ise nüfus değişkeni yer almaktadır. Şekilde, gelirin dağılımının nasıl gerçekleştiğini mutlak eşitlik çizgisi ve Lorenz eğrisi ifade etmektedir. Bu bağlamda, mutlak eşitlik çizgisi üzerindeki noktalarda gelir, ütopik bir şekilde eşit olarak dağıtılmaktadır. Mutlak eşitlik çizgisinden sapmalar ise Lorenz eğrisi ile belirtilmektedir. Bu bağlamda; eşitsizlik ne kadar artarsa, Lorenz eğrisi mutlak eşitlik çizgisinden o kadar uzaklaşır ve gelir dağılımı o kadar adaletsiz olur (Pınar, 2019: 288). 
Gini katsayısı; bir ülkede bir yılda elde edilen gelirin nüfusa hangi oranda eşit paylaştırıldığını belirlemek amacıyla kullanılan bir katsayıdır. Gini katsayısı; mutlak eşitlik çizgisi ile Lorenz eğrisi arasındaki alanın, mutlak eşitlik çizgisi altında kalan alanın tamamına oranı şeklinde hesaplanır.

Gini Katsayısı $=\frac{B}{A+B}$

0 ile 1 arasında değerler alabilen Gini katsayısı, 0’a yaklaştıkça gelir dağılımı adaletsizliği azalmakta, 1'e yaklaştıkça gelir dağılımı adaletsizliği artmaktadır. Gini katsayısının 0'a eşit olması durumunda, ilgili ülkedeki gelir dağılımının tam olarak adil olduğu; 1'e eşit olması durumunda ise, ilgili ülkedeki gelir dağılımının tamamen adaletsiz olduğu kabul edilmektedir (Karaman ve Özçalık, 2007, s. 27). Tablo 1'de, OECD ülkelerinden bazılarına ait olan Gini katsayıları gösterilmiştir.

Tablo 1. Bazı OECD Ülkelerinde Gini Katsayıları

\begin{tabular}{|c|c|c|c|c|c|c|c|c|c|}
\hline & $\mathbf{2 0 1 0}$ & $\mathbf{2 0 1 1}$ & $\mathbf{2 0 1 2}$ & $\mathbf{2 0 1 3}$ & $\mathbf{2 0 1 4}$ & $\mathbf{2 0 1 5}$ & $\mathbf{2 0 1 6}$ & $\mathbf{2 0 1 7}$ & $\mathbf{2 0 1 8}$ \\
\hline Kanada & 0.31 & 0.308 & 0.309 & 0.312 & 0.307 & 0.306 & 0.304 & 0.304 & 0.304 \\
\hline Çekya & 0.253 & 0.252 & 0.251 & 0.252 & 0.252 & 0.251 & 0.249 & 0.248 & 0.247 \\
\hline Macaristan & 0.27 & 0.273 & 0.276 & 0.278 & 0.277 & 0.276 & 0.277 & 0.278 & 0.279 \\
\hline İsrail & 0.368 & 0.367 & 0.366 & 0.362 & 0.358 & 0.355 & 0.351 & 0.35 & 0.349 \\
\hline G. Kore & 0.312 & 0.312 & 0.31 & 0.311 & 0.313 & 0.317 & 0.323 & 0.327 & 0.331 \\
\hline Y. Zelanda & 0.319 & 0.321 & 0.322 & 0.325 & 0.328 & 0.329 & 0.33 & 0.33 & 0.33 \\
\hline Norveç & 0.244 & 0.242 & 0.244 & 0.25 & 0.251 & 0.255 & 0.256 & 0.256 & 0.256 \\
\hline Polonya & 0.308 & 0.306 & 0.307 & 0.311 & 0.302 & 0.295 & 0.29 & 0.288 & 0.286 \\
\hline İsveç & 0.252 & 0.253 & 0.254 & 0.256 & 0.256 & 0.258 & 0.26 & 0.261 & 0.262 \\
\hline İsviçre & 0.286 & 0.284 & 0.284 & 0.287 & 0.286 & 0.287 & 0.288 & 0.289 & 0.29 \\
\hline Türkiye & 0.406 & 0.403 & 0.402 & 0.4 & 0.4 & 0.401 & 0.401 & 0.4 & 0.4 \\
\hline İngiltere & 0.333 & 0.331 & 0.328 & 0.328 & 0.328 & 0.329 & 0.331 & 0.328 & 0.329 \\
\hline ABD & 0.37 & 0.375 & 0.377 & 0.379 & 0.381 & 0.381 & 0.382 & 0.382 & 0.382 \\
\hline
\end{tabular}

Kaynak: Organisation for Economic Co-operation and Development [OECD], 2020a.

Tablo 1'de gösterilen GINI katsayısı değerleri incelendiğinde, gelir dağılımında adaletin en çok sağlandığı ülke Çekya'dır. Çekya'da, GINI katsayısı değerleri 2010 yılından 2018 yılına kadar istikrarlı bir şekilde hareket etmiş ve 2018 yılında 0,247 olmuştur. Tabloya göre, gelir dağılımında adaletin en az sağlandığı ülke ise Türkiye'dir. Bu bağlamda, Türkiye'de GINI katsayısı değerleri 2010 yılından 2018 yılına kadar 0,4 değerinin altına hiç düşmemiştir. 
Gelir dağılımının adaletli bir şekilde yapılması, demokratik yönetimlerin devamlılığında şarttır. Bu kapsamda, gelir dağılımında sağlanan adalet; tüketimin artmasında, yatırım ve potansiyel vergi kapasitesinin artırılmasında, ekonomik büyümenin gerçekleştirilmesinde, sosyal huzurun sağlanması ve korunmasında, çalışma motivasyonunun ve üretkenliğin artırılmasında, nihayetinde de ekonomik ve siyasal istikrarın sağlanmasında önemli bir olgudur (Öztürk, 2017, s. 7-8). Sonuç olarak; devletlerin, gelir dağılımı eşitsizliğini azaltan adil bir gelir dağılımı politikası izlemesi kaçınılmaz bir gerçektir (Öztürk, 2009, s. 9).

\section{SOSYAL AMAÇLI TRANSFER HARCAMALARI VE OECD ÜLKELERİNDEKİ SEYRİ}

1930'lu yıllardan itibaren önemi daha da artan transfer harcamaları, milli gelir üzerinde doğrudan bir etki meydana getirmeyen ve satın alma gücü yetersiz olan kişilere ya da sosyal gruplara karşılıksız olarak, kazanç amacı güdülmeden intikal ettirilen harcamalardir (Heald ve McLeod, 2002, s. 2). Genel olarak transfer harcamaları; çalışanların tazminatı, mal ve hizmet kullanımı, sabit sermaye tüketimi, borç faiz harcamaları, sübvansiyonlar, hibeler, sosyal yardımlar ve diğer harcamalar olmak üzere farklı gruplara ayrılmaktadır (International Monetary Fund [IMF], 2001).

Transfer harcamaları; merkezi idarenin mahalli idarelere yaptı̆̆ı mali yardımlar, devlet borçlarının faiz ödemeleri, sosyal amaçlı transfer harcamaları, iktisadi ve mali transfer harcamaları olmak üzere 4 temel gruba ayrılır. Çalışmanın temel konusu olan sosyal amaçlı transfer harcamaları; gelir dağılımında adaleti sağlamak amacıyla emekliler, dul ve yetimler, muhtaç öğrenciler, şehit aileleri ve gaziler, işsizler gibi gruplara yapılan karşılıksız ödemeleri içermektedir. Bu bağlamda, devletin, gelir dağılımını gelir düzeyi düşük sınıflar lehine değiştirmek suretiyle yapmış olduğu harcamalar, sosyal amaçlı transfer harcaması olarak değerlendirilmektedir. Gelişmekte olan ülkelerde, milli gelirin düşük olması bağlamında yatırım harcamalarına daha fazla önem verilmesi zorunluluğu sosyal amaçlı transfer harcamalarına daha az ağırlık verilmesine neden olmaktadır. Dolayısıyla, sosyal amaçı transfer harcamaları genellikle gelişmiş ülkelerde daha fazla 
kullanılan bir maliye politikası aracıdır (Chu vd., 2000, s. 10). Tablo 2'de bazı OECD ülkelerindeki sosyal amaçlı transfer harcamalarının GSYH'ye oranları verilmiştir.

Tablo 2. Bazı OECD Ülkelerinde Sosyal Amaçlı Transfer Harcamaları/GSYH Oranı

\begin{tabular}{|c|c|c|c|c|c|c|c|c|c|c|c|}
\hline & 2008 & 2009 & 2010 & 2011 & 2012 & 2013 & 2014 & 2015 & 2016 & 2017 & \\
\hline Avus & 25,5 & 27,5 & 27,6 & & 27,1 & 27,5 & 27,7 & 27,7 & 7,8 & 27,1 & \\
\hline Belçi & 26,3 & 28,6 & 8,3 & & 28,7 & 29,2 & 29,4 & 9,2 & & 29,2 & \\
\hline Çel & 7,8 & 20,1 & 19,7 & 19,8 & 20,0 & 20,9 & 20,2 & 19,4 & 9,1 & 19,0 & \\
\hline & 25,4 & 28,3 & 28,6 & 28,6 & 28,7 & 28,8 & 28,8 & 29,0 & 28,7 & 28,1 & 28, \\
\hline & 15,4 & 19,5 & 18,3 & 16,3 & 15,9 & 15,8 & 16,4 & 17,7 & 18,3 & 18,0 & 8, \\
\hline Fran & 28,3 & 31,0 & 31,0 & 30,8 & 31,4 & 31,9 & 32,2 & 32,0 & 32,0 & 31,8 & 1， \\
\hline Alm & 24,2 & 26,6 & 25,9 & 24,7 & 24,5 & 24,7 & 24,7 & 24,9 & 25,1 & 25,1 & 5, \\
\hline Yunar & 21,3 & 24,0 & 24,9 & 26,0 & 26,9 & 25,1 & 25,2 & 25,4 & 25,7 & 24,8 & 23,5 \\
\hline Macar & 22,7 & 23,3 & 23,0 & 22,4 & 22,7 & 22,3 & 21,5 & 20,9 & 20,8 & 20,2 & 19, \\
\hline Isra & 4,8 & 15,3 & 15,4 & 15,2 & 15,5 & 15,5 & 15,5 & 15,5 & 15,5 & 16,0 & 16 \\
\hline İtal & 5,1 & 27,1 & 27,1 & 26,8 & 27,6 & 28,2 & 28,4 & 28,5 & 28,3 & 28,1 & 27, \\
\hline & & & & & 8,7 & 9,3 & 7 & 10,2 & 0,5 & 10,6 & 11, \\
\hline Letc & & & & & 15,4 & 15,5 & 5,4 & & 0,1 & & 6,2 \\
\hline Litva & 16,6 & 21,8 & 19,4 & & 16,5 & 15,5 & 15,6 & & 6,0 & 15 & 16 \\
\hline Hollanda & 15,7 & 17,4 & 17,8 & 17,7 & 18,2 & 18,5 & 18,1 & 17,7 & 17,5 & 17,0 & 16,7 \\
\hline & 19,2 & 22,4 & 22,0 & 21,5 & 21,4 & 21,9 & 22,8 & 24,7 & & 25, & 25,0 \\
\hline & 22,2 & 24,5 & 24,5 & 24,4 & 24,5 & 25,6 & 25,1 & 24,0 & 23,7 & 23,7 & $22,($ \\
\hline & 15,3 & 18,2 & 18,0 & 17,7 & 17,8 & 18,0 & 18,1 & 17,8 & 17,8 & 17,3 & 17,0 \\
\hline Slov & 19,9 & 22,5 & 23,4 & 23,5 & 23,5 & 23,8 & 23,1 & 22,6 & 22,2 & 21,4 & 1,2 \\
\hline İspan & 22,2 & 25,4 & 4,7 & 25,4 & 25,3 & 25,6 & 25,2 & 24,7 & 24,3 & 23,9 & 23,7 \\
\hline Isveç & 25,6 & 27,6 & 26,3 & 25,6 & 26,5 & 27,2 & 26,8 & 26,3 & 26,4 & 26,1 & 20, \\
\hline İsviçr & 13,8 & 15,3 & 15,1 & & 15,3 & 15,4 & 15,5 & 15,9 & 15,9 & 16,1 & 16,0 \\
\hline Türk & & & 12, & & 12,0 & 11,8 & & 11,6 & 12,5 & 12,1 & 12,0 \\
\hline İngilt & 20,1 & 22, & 22,4 & & 22,2 & 22,5 & 21,9 & 21,6 & 21,2 & 20,8 & 20,6 \\
\hline & 16,5 & 18 & 19,4 & & 18,8 & 18,8 & & 18,8 & 18,9 & 18,9 & 8,7 \\
\hline - & & & & & 20,3 & 20,4 & & 19,0 & & & \\
\hline
\end{tabular}

Tablo 2'ye göre, 2008 yılından sonra, Küresel Krizin etkisini yitirmeye başlamasıyla birlikte, sosyal amaçlı transfer harcamalarında genel olarak artış görülmektedir. OECD ülkelerindeki genel ortalamaya baktığımızda bu oranın; 2008 yılında Küresel Krizden dolayı \%18,5 olduğunu, 2009 yılından 2018 yılına kadarki dönemde ise \%20 civarında olduğunu görürüz. Tabloya göre, sosyal amaçlı transfer harcamaları/GSYİH oranı en yüksek olan ülke Fransa'dır. Fransa'da, 2009 yılından 2018 yılına kadar olan zaman diliminde bu oran her yıl \%30'un üzerindedir. 
Avusturya, Belçika, Danimarka, Almanya, İtalya, Norveç ve İsveç gibi OECD ülkelerinde ise bu oran, \%20'lerin üzerinde, genel olarak \%30'lara daha yakındır. Aksine, bu oran, Güney Kore, İsviçre, ABD, Letonya, Litvanya, Slovakya ve Slovenya gibi OECD ülkelerinde \%20'lerin altındadır. Türkiye'de ise bu oran, OECD ortalamasının çok altında olup 2018 yılında \%12,6 olarak gerçekleşmiştir.

Tablo 3. Bazı OECD Ülkelerinde 2015 Yılına Ait Sosyal Amaçlı Transfer Harcamalarının Kalemleri/GSYH Oranları

\begin{tabular}{|c|c|c|c|c|c|c|c|c|c|}
\hline & 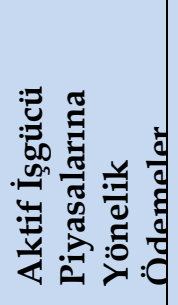 & 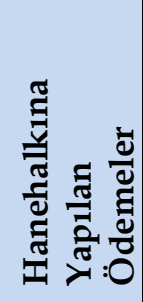 & 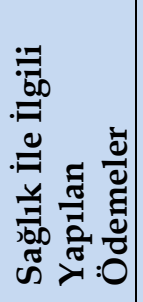 & 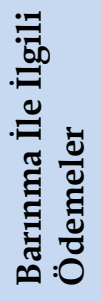 & 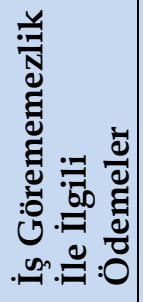 & 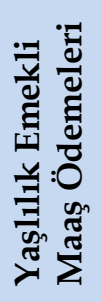 & 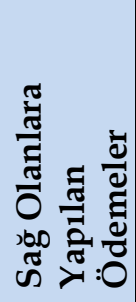 & 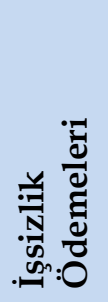 & 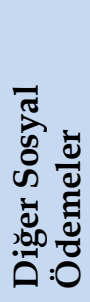 \\
\hline Avusturya & 0,70 & 2,60 & 6,50 & 0,10 & 2,50 & 12,20 & 1,70 & 1,1 & 0,60 \\
\hline Belçika & 0,70 & 2,80 & 7,90 & 0,20 & 2,90 & 9,10 & 1,80 & 2,9 & 0,70 \\
\hline Çekya & 0,40 & 2,00 & 6,00 & 0,30 & 1,70 & 7,70 & 0,60 & 0,5 & 0,20 \\
\hline Danimarka & 2,10 & 3,40 & 6,70 & 0,70 & 4,40 & 10,20 & 0,00 & 0,00 & 1,50 \\
\hline Estonya & 0,20 & 2,80 & 4,80 & 0,00 & 2,30 & 7,00 & 0,10 & 0,3 & 0,10 \\
\hline Fransa & 1,00 & 2,90 & 8,80 & 0,80 & 1,70 & 12,70 & 1,70 & 1,6 & 0,80 \\
\hline Almanya & 0,60 & 2,20 & 8,10 & 0,60 & 2,10 & 8,30 & 1,80 & 0,9 & 0,30 \\
\hline Yunanistan & 0,30 & 1,00 & 4,80 & 0,00 & 1,90 & 14,30 & 2,70 & 0,5 & 0,10 \\
\hline Macaristan & 0,90 & 3,00 & 4,80 & 0,30 & 1,90 & 8,60 & 1,10 & 0,3 & 0,10 \\
\hline İsrail & 0,10 & 1,90 & 4,60 & 0,00 & 2,50 & 4,70 & 0,60 & 0,3 & 0,70 \\
\hline İtalya & 0,50 & 2,00 & 6,70 & 0,00 & 1,80 & 13,60 & 2,60 & 1 & 0,20 \\
\hline G. Kore & 0,40 & 1,20 & 4,00 & 0,00 & 0,60 & 2,70 & 0,30 & 0,3 & 0,70 \\
\hline Letonya & 0,10 & 2,10 & 3,30 & 0,10 & 2,10 & 7,20 & 0,20 & 0,5 & 0,10 \\
\hline Litvanya & 0,30 & 1,70 & 4,30 & 0,00 & 2,00 & 6,50 & 0,40 & 0,2 & 0,30 \\
\hline Hollanda & 0,80 & 1,50 & 2,70 & 0,50 & 3,40 & 6,10 & 0,10 & 1,5 & 1,20 \\
\hline Norveç & 0,50 & 3,30 & 6,40 & 0,10 & 4,30 & 8,50 & 0,30 & 0,4 & 0,80 \\
\hline Portekiz & 0,50 & 1,20 & 5,90 & 0,00 & 1,80 & 11,60 & 1,90 & 1 & 0,20 \\
\hline Slovakya & 0,20 & 2,00 & 5,50 & 0,00 & 1,90 & 6,80 & 0,90 & 0,4 & 0,30 \\
\hline Slovenya & 0,20 & 1,80 & 6,10 & 0,00 & 2,00 & 9,80 & 1,50 & 0,5 & 0,70 \\
\hline İspanya & 0,60 & 1,20 & 6,50 & 0,10 & 2,40 & 9,30 & 2,30 & 2,0 & 0,20 \\
\hline İsveç & 1,30 & 3,50 & 6,30 & 0,40 & 4,10 & 9,10 & 0,30 & 0,3 & 0,90 \\
\hline İsviçre & 0,60 & 1,70 & 3,00 & 0,10 & 2,20 & 6,30 & 0,50 & 0,8 & 0,70 \\
\hline Türkiye & 0,00 & 0,40 & 3,20 & 0,00 & 0,40 & 5,70 & 1,40 & 0,2 & 0,20 \\
\hline İngiltere & 0,20 & 3,50 & 7,70 & 1,50 & 1,90 & 6,50 & 0,10 & 0,2 & 0,10 \\
\hline ABD & 0,10 & 0,60 & 8,40 & 0,30 & 1,40 & 6,40 & 0,70 & 0,2 & 0,80 \\
\hline OECD - Total & 0,40 & 2,00 & 5,30 & 0,30 & 1,90 & 7,00 & 0,90 & 0,7 & 0,50 \\
\hline
\end{tabular}

Kaynak: OECD, 2020b.

OECD'nin sosyal amaçlı transfer harcamaları tanımında; aktif işgücü piyasalarına yönelik ödemeler, hane halkına yapılan ödemeler, sağlık ile ilgili ödemeler, barınma ile ilgili ödemeler, iş görememezlik ile ilgili ödemeler, yaşlılık emekli maaş ödemeleri, să̆ olanlara yapılan ödemeler, işsizlik ödemeleri ve diğer sosyal ödemeler yer almaktadır (OECD, 2020b). Tablo 3'te, 2015 yılında, bazı OECD 
ülkelerindeki sosyal amaçlı transfer harcama kalemlerinin, o ülkelerin GSYH'lerine oranları yer almaktadir.

Tablo 3'te görüldüğü üzere; 2015 yılında yaşl1lık emekli maaş ödemeleri, sosyal harcama kalemleri arasında genel olarak en yüksek orana sahip olan kısımdır. İkinci sırada ise sağlıkla ilgili ödemeler yer almaktadır. Tabloda yer alan ülkelere genel olarak bakıldığında, işsizlik ödemelerinin düşük olduğu görülmektedir. Türkiye'ye baktığımızda ise, sosyal amaçlı transfer harcamalarının tüm kalemlerinin, OECD ortalamasının çok altında olduğunu görürüz.

\section{LITERATÜR TARAMASI}

Kamu harcamalarının gelir dağılımına etkisini inceleyen pek çok çalışma bulunmaktadır. Bu çalışmaların bir kısmında kamu harcamaları bir bütün olarak ele alınmıştır, diğer kısmında ise sınıflandırmalardan yararlanılarak farklı harcama türlerinin etkileri dikkate alınmıştır.

Gustafsson ve Johansson (1999), 16 OECD ülkesinin 1966-1994 dönemine ait ilgili verilerini Panel Veri Analizi Yöntemi'ni kullanarak incelemişlerdir. Çalışmalarının sonucunda; sosyal amaçlı transfer harcamalarının gelir dağılımı üzerinde herhangi bir etkiye sahip olmadığını belirtmişlerdir. Li vd. (2000), yapmış oldukları çalışmada, 84 yüksek gelirli ve orta gelirli ülkenin1980-1998 yılları arasına ait verilerini Panel Veri Analizi Yöntemi ile incelemiştir. Gini katsayısının bağımlı değişken, kişi başına reel gelir ile kamu harcamalarının GSYH içerisindeki payının açıklayıcı değişken olarak kullanıldığı çalışmalarının sonucunda; gelir vergilerinin ve kamu harcamalarının gelir eşitsizliğini azalttığı yönünde tespitte bulunmuşlardır. Keane ve Prasad (2002), çalışmalarında, Polonya'da 1988-1997 dönemine ait verileri Basit Korelasyon Hesaplama Yöntemi'ni kullanarak incelemişlerdir. Çalışmalarının sonucunda; sosyal transfer harcamalarının, eşitsizlik ve yoksulluk olgularında yaşanan artışların azaltılmasında önemli bir rol oynadığını belirlemişlerdir. Sylwester (2002), 50 ülkeye ait 1970-1990 dönemi verilerini Panel Veri Analizi Yöntemi'ni kullanarak incelemiştir. Bu bağlamda, eğitime daha fazla kaynak tahsis edilmesinin bir ülkedeki gelir eşitsizliği seviyesini azalttı̆̆ı yönünde bir sonuca ulaşmışlardır. Schwabish vd. (2004), yapmış oldukları çalışmada, 17 ülkenin 1984, 1990-1993 ve 1995- 
1997 dönemlerine ait verileri Panel Veri Analizi Yöntemi ile incelemişlerdir. Çalışmalarının sonucunda; sosyal amaçlı transfer harcamaları ile gelir eşitsizliği arasındaki ilişkinin gelir gruplarına göre değiştiğini ifade etmişlerdir. Sosyal amaçlı transfer harcamalarının; orta sınıflara ve yoksullara olan etkisinin pozitif yönde olduğunu, orta sınıfın altındaki sınıflara olan etkisinin ise negatif yönde olduğunu açıklamışlardır. Huber vd. (2004), EKK (En Küçük Kareler) Yöntemi’ni kullanarak Latin Amerika ve Karayipler'de bulunan 18 ülkenin 1970-1995 dönemine ait sağl1k, eğitim ve sosyal harcamalarının gelir dağılımı üzerindeki etkisini incelemişlerdir. Yapmış oldukları çalışmalarının sonucunda; eğitim ve sağlık harcamalarının gelir eşitsizliğini artırdığı, sosyal güvenlik ve refah harcamalarının ise (özellikle emekli maaşlarının) gelir eşitsizliğini azalttığı yönünde yargıya varmışlardır. Afonso vd. (2010), yapmış oldukları çalışmalarında, 26 OECD ülkesinde 1995-2000 dönemine ait verileri Veri Zarflama Analizi Yöntemi'ni kullanarak, kamu harcamaları ile gelir eşitsizliği arasında ilişkiyi araştırmışlardır. Yapmış oldukları çalışmalarının sonucunda; kamu harcamalarının özellikle de eğitim alanındaki harcamaların, gelir eşitsizliğini azalttı̆̆ını ifade etmişlerdir. Niehues (2010), 15 AB ülkesinde, 1993-2006 dönemine ait verileri dikkate alıp Panel Veri Analizi Yöntemi'ni kullanarak, sosyal harcamaların gelir dağılımı üzerindeki etkisini incelemiştir. Çalışmasının sonucunda; sosyal harcamalarda özellikle de işsizlik yardımı ile emekli aylıklarında yaşanacak olan artışın, gelir eşitsizliğini azalttığı yönünde tespitte bulunmuştur. Hazman (2011), Hata Düzeltme Modeli'ni kullanarak sosyal güvenlik harcamaları ile gelir eşitsizliği arasındaki ilişkiyi, 1980-2005 yılları arasındaki verileri baz alarak Türkiye'de incelemiştir. Çalışmasının sonucunda, gelir dağılımından kamu harcamalarına doğru ve sosyal güvenlik harcamalarından kamu harcamalarına doğru tek yönlü nedensellik ilişkisi tespit etmiştir. Bu bağlamda, sosyal güvenlik harcamalarının ve gelir eşitsizliğinin artması, kamu harcamalarının artmasında etkili olmaktadır. Holzner (2011), kamu harcamaları ile gelir eşitsizliği ve ekonomik büyüme değişkenleri arasındaki ilişkileri; Orta, Doğu ve Güneydoğu Avrupa'da yer alan 8 ülkenin 19892006 dönemine ait olan verilerini, EKK (En Küçük Kareler) Yöntemi ve dinamik panel tahmin yöntemlerinden biri olan GMM (Genelleştirilmiş Momentler Metodu) Yöntemi ile analiz etmiştir. Çalışmasının sonucunda; özellikle, kamu harcamalarından sosyal 
amaçlı transfer harcamaları ile gelir eşitsizliği arasında negatif yönlü bir ilişki tespit etmiştir. O halde, gelir adaletsizliğinin azaltılabilmesi için sosyal amaçlı transfer harcamalarının artırılması şarttır. Caminada vd. (2012), 20 OECD ülkesinin 1985-2005 dönemine ait verilerini, Panel Veri Analizi Yöntemi'ni kullanarak sosyal transfer harcamaları ile vergilerin gelir dağılımına etkisi bağlamında incelemişlerdir. Çalışmalarının sonucunda; sosyal transfer harcamalarının gelir eşitsizliğini azaltma hususunda, vergilerden çok daha fazla etkili olduğunu belirtmişlerdir. Wang vd. (2012), sosyal transfer harcamaları ile vergilerin gelir dağılımına etkisini, 28 OECD ülkesinde 1995-2007 dönemine ait verileri Panel Veri Analizi Yöntemi'ni kullanarak incelemişlerdir. Çalışmalarının sonucunda; sosyal transfer harcamalarının, özellikle de kamu emeklilik maaş ödemelerinin gelir adaletsizliğini azaltma konusunda vergilerden çok daha fazla etkin olduğu yargısına ulaşmışlardır. Ancak, sosyal transfer harcamaları içerisinde kamu emeklilik maaş ödemeleri, gelir eşitsizliğini azaltma hususunda; diğer sosyal ödemeler, iş görememezlik yardımları ve aile ile ilgili yardımlara göre daha çok etkindir. Woo vd. (2013), sosyal amaçlı transfer harcamaları ve sübvansiyonlar ile gelir eşitsizliği değişkenleri arasındaki ilişkiyi, 17 OECD ülkesinin 1978-2010 dönemine ait ilgili verilerini Panel Veri Analizi ve EKK (En Küçük Kareler) Yöntemleri'ni kullanarak incelemişlerdir. Çalışmalarının sonucunda; sosyal amaçı transfer harcamaları ile sübvansiyonların, gelir eşitsizliğini azalttı̆̆ını belirtmişlerdir. Martínez-Vázquez vd. (2014), vergilerin ve bazı kamu harcamalarının gelir dağılımına etkisini, 150 ülkenin 1970-2009 dönemine ait oldukça geniş bir panel veri setini GMM Yöntemi'ni kullanarak incelemişlerdir. Bu bağlamda, sosyal amaçlı transfer harcamalarının gelir eşitsizliğini azalttığı sonucuna ulaşmışlardır. İlgün (2015), kamu sosyal harcamalarının gelir dağılımı üzerindeki etkisini, 17 OECD ülkesinin 1995-2012 dönemine ait verilerini Panel Veri Analizi Yöntemi'ni kullanarak incelemiştir. Kamu sosyal harcamalarının gelir dağılımı üzerindeki etkisini, hem toplam harcamalar hem de sosyal harcamaların alt bileşenleri olarak incelediği çalışmasının sonucunda; kamu sosyal harcamaları, dul ve yetim aylıkları, aktif işgücü piyasalarına yönelik ödemeler ile işsizlik ödemelerinin GSYH içindeki payının artmasının, gelir dağılımı eşitsizliğini azalttığı yönünde bir tespitte bulunmuşlardır. D’Agostino vd. (2016), sosyal transfer harcamaları ile gelir dağılımı arasındaki ilişkiyi, 
21 OECD ülkesinin 1995-2010 dönemine ait olan verilerini Zaman Serileri Regresyon Analiz Yöntemi'ni kullanarak araştırmışlardır. Çalışmalarının sonucunda; kamu harcamalarındaki \%1'lik artışın Gini Katsayısı'nı 0,5 puan düşürdügünü ifade etmişlerdir. Cimoli vd. (2017), Latin Amerika'da yer alan gelişmiş ve gelişmekte olan ülkelerin 1990-2010 dönemine ait verilerini Basit Korelasyon Analizi Yöntemi'ni kullanarak sosyal harcamalar ile gelir dağılımı arasındaki ilişkiyi incelemişlerdir. Çalışmalarının sonucunda; sosyal harcamaların gelir eşitsizliğini azaltmak hususunda etkinliği yadsınamaz olmasına rağmen, sürdürülebilir eşitliğin sağlanabilmesi bağlamında yapısal değişikliklerin şart olduğu belirtilmiştir. Eroğlu vd. (2017), çalışmasında, sosyal yardım harcamalarının gelir dağılımına etkisini, Türkiye'nin içinde bulunduğu 21 OECD ülkesinin 2004-2011 dönemine ait verilerini Panel Veri Analizi Yöntemi'ni kullanarak incelemişlerdir. Yapmış oldukları çalışmalarının sonucunda, sosyal yardım harcamalarının gelir dağılımına etkisinin olumlu yönde olduğunu ifade etmişlerdir. Bu bağlamda, sosyal yardım harcamaları arttığında gelir dağılımı eşitsizliği azalmaktadır. Ürper (2018), kamu harcamalarının gelir eşitsizliğine etkisini, Türkiye'de 1987-2016 dönemini dikkate alarak Regresyon Analiz Yöntemi ile incelemiştir. Çalışmasının sonucunda; sosyal amaçlı transfer harcamalarının gelir eşitsizliğini azalttı̆̆ını, cari harcamaların ise gelir eşitsizliğini artırdı̆̆ını belirtmiştir. Kozuharov ve Petkovski (2018), sosyal transfer harcamalarının gelir eşitsizliğine etkisini Makedonya'nın 2002-2014 yılları arasındaki ilgili verilerini dikkate alıp, regresyon ve korelasyon analizlerini kullanarak incelemişlerdir. Çalışmalarının sonucunda; sosyal transfer harcamalarında yaşanan artışın gelir eşitsizliğini azaltacağı yönünde bir karara varmışlardır. Bu bağlamda, bir ülkede gelir dağılımın adil bir şekilde yapılması; tüketimi, sürdürülebilir büyümeyi ve sosyal refahı da artıracaktır. Ulu (2018), sosyal transfer harcamaları ile gelir eşitsizliği arasındaki ilişkiyi, 21 OECD ülkesinin 2004-2011 dönemine ait verilerini Panel Veri Analizi Yöntemi'ni kullanarak incelemiştir. 1990'lardan itibaren OECD'nin çoğunda gelir eşitsizliğinin arttığını belirten çalışmanın sonucuna göre; devletin sosyal alanda yapmış olduğu harcamalar gelir eşitsizliğini azaltmaktadır. Yardımcıŏ̆lu ve Yayla (2020), 7 Orta ve Doğu Avrupa ülkesinde, 2005-2017 yılları arasında sosyal koruma harcamaları ile emekli maaş ödemelerinin gelir dağılımı üzerindeki etkisini Panel Veri Analizi Yöntemi'ni 
kullanarak incelemiştir. Çalışmalarının sonucunda; emekli maaş ödemelerinin sürekli olması sebebiyle gelir eşitsizliğini azalttı̆̆ı̆, sosyal koruma harcamalarının ise ülkelerin gelişmişlik düzeyine bağlı olarak değişiklik göstermesi nedeniyle istatistiki olarak gelir eşitsizliği üzerinde anlamlı etkiye sahip olmadığı yönünde bir neticeye ulaşmışlardır.

\section{EKONOMETRİK ANALIZ}

\subsection{Veri Seti}

$\mathrm{Bu}$ çalışmada sosyal amaçlı transfer harcamalarının gelir dağılımına etkisi, 36 OECD ülkesinin 1996-2018 dönemi verileri kullanılarak analiz edilmiştir. Çalışmada bağımlı değişken olarak; GINI katsayısı, bağımsız değişken olarak hane halkına yönelik transfer ödemelerinin milli gelire oranı verileri kullanılmıştır. Ayrıca ekonomik büyüme oranı ve nüfus artış hızı verileri de kontrol değişkenleri olarak analize dâhil edilmiştir. GINI katsayılarına Harvard Üniversitesi Veri Bankasında yer alan ve Frederick (2019) tarafından hazırlanan The Standardized World Income Inequality Database, Version 8'den ulaşılmıştır. Transfer ödemelerine OECD (2020b)'den, ekonomik büyüme ve nüfus verilerine World Bank (2020a, 2020b)'den erişilmiştir. Ayrıca analiz döneminde yer alan ve genel olarak bütün ülkeleri etkileyen 2008 küresel ekonomik krizi de kukla değişken ile analize dâhil edilmiştir. Bu kukla değişken oluşturulurken; krizin etkisinin en yüksek olduğu 2008 ve 2009 yıllarına 1, diğer yıllara 0 değerleri verilmiştir. Çalışmanın zaman boyutu $\mathrm{T}=23$, yatay kesit boyutu $\mathrm{N}=36$ olmak üzere analizlerde 828 verilik dengeli bir panel kullanılmıştır. Veri setine ait tanımlayıcı istatistikler Tablo 4 'te yer almaktadır: 
Tablo 4. Tanımlayıcı İstatistikler

\begin{tabular}{lcccc}
\hline & GINI & TR & G & POP \\
\hline Ortalama & 30.85 & 19.21 & 2.76 & 0.55 \\
\hline Ortanca & 30.6 & 18.93 & 2.79 & 0.49 \\
\hline Max. & 48.5 & 32.21 & 25.16 & 2.89 \\
\hline Min. & 21.8 & 3.22 & -14.81 & -2.26 \\
\hline Std. Sapma & 5.57 & 5.83 & 3.13 & 0.77 \\
\hline Çarpıklık & 1.11 & -0.29 & -0.37 & -0.09 \\
\hline Basıklık & 4.26 & 2.87 & 10.01 & 3.69 \\
\hline Jarque-Bera & 224.93 & 12.16 & 1714.79 & 17.72 \\
\hline Olasılık & 0.00 & 0.002 & 0.00 & 0.0001 \\
\hline Gözlem & 828 & 828 & 828 & 828 \\
\hline
\end{tabular}

Tablo 4'teki bilgilere göre OECD ülkelerinde GINI katsayısı 21.8 (Danimarka, 1995) ile 48.5 (Şili, 1998) arasında değişen değerler almıştır. Bu da ülkeler ve dönemler itibariyle OECD ülkelerinde gelir dağılımı noktasında önemli farkların olduğunu göstermektedir. Transfer ödemelerinin milli gelire oranının en fazla \%32,21 (Fransa, 2014), en düşük \%3.22 (G. Kore, 1996) olduğu görülmektedir. Ekonomik büyümenin en düşük -\%14.81 (Litvanya, 2009), en yüksek \%25.16 (İrlanda, 2015) olduğu dikkati çekmektedir. Nüfus artış hızının ise en düşük -\%2.26 (Litvanya) ve en yüksek \%2.89 (İrlanda, 2007) olduğu belirlenmiştir. Verilerin standart sapmaları düşük, çarpıklık ve basıklık sorunu yoktur. Çalışmada kullanılan gözlem sayısı 828 olup, serbestlik derecesi ve güvenilirliği yüksek bir panel veri analizi yapabilmek için oldukça yeterlidir. Değişkenler arasındaki korelasyon matrisi Tablo 5'te yer almaktadır.

Tablo 5. Korelasyon Matrisi

\begin{tabular}{lcccc}
\hline & GINI & TR & G & POP \\
\hline GINI & 1 & -0.62 & 0.09 & 0.21 \\
\hline TR & -0.62 & 1 & -0.35 & -0.21 \\
\hline G & 0.09 & -0.35 & 1 & 0.07 \\
\hline POP & 0.21 & -0.21 & 0.07 & 1 \\
\hline
\end{tabular}

Korelasyon; iki değişkenin birlikte hareket etme eğiliminin bir ölçüsü olup, korelasyon katsayıları $(-1,+1)$ aralığında değişen değerler alırlar. Korelasyon katsayısının mutlak değerce 1'e yaklaşması; değişkenler arasındaki ilişkinin güçlü olduğunu, katsayının 0'a yaklaşması, değişkenler arasındaki ilişkinin zayıf olduğunu 
gösterir. Son olarak; korelasyon katsayısının işareti, değişkenler arasındaki ilişkinin yönü hakkında bilgiler sağlar. Pozitif işaret; aynı yönlü, negatif işaret; zıt yönlü ilişkiyi betimler (Samuels ve Gilchrist, 2014).

$\mathrm{Bu}$ çalışmada kullanılan değişkenlerde transfer ödemelerinin (TR), gelir dağılımı dengesizliği ile zıt yönlü ve güçlü bir ilişki içinde olduğu görülmektedir. Nüfus artış hızı (POP) ve ekonomik büyüme (G), gelir eşitsizliği ile aynı yönlü, ama görece daha zayıf ilişkilere sahiptir.

\subsection{Model}

$\mathrm{Bu}$ çalışmada sosyal amaçlı transfer harcamalarının gelir dağılımına etkisini araştırabilmek için aşağıdaki modelden yararlanılmıştır:

$$
G I N I_{i t}=\beta_{0 i}+\beta_{1 i} T R_{i t}+\beta_{2 i} G_{i t}+\beta_{3 i} P O P_{i t}+\beta_{4 i} K_{2008}+\varepsilon_{i t}
$$

Burada GINI; gelir eşitsizliğini ölçen endeks olup, $(0,100)$ aralığında değerler almaktadır. Bu değerin 0’a yaklaşması; ilgili ülkede gelir dağılım eşitsizliğinin azaldığını, 100'e yaklaşması gelir dağılım eşitsizliğinin arttığını göstermektedir. TR; Hanehalkına yönelik devletler tarafından yapılan transfer ödemelerinin milli gelire oranını (\%), G; ekonomik büyüme oranını (\%), POP; nüfus artış hızını (\%) ve $K_{2008}$; 2008 küresel ekonomik krizini temsil eden kukla değişkeni ifade etmektedir. $i$; yatay kesitleri (bu çalışmada ülkeleri), $t$; zamanı, $\varepsilon_{i t}$; White Noise sürecine sahip hata terimleri serisini ifade etmektedir.

Transfer ödemelerinin ülkelerdeki gelir dağılım eşitsizliğini azaltması beklendiği için yapılacak analizler sonucunda $\beta_{1 i}<0$ çıkması öngörülmektedir. Ekonomik büyümenin gelir dağılım eşitsizliği üzerindeki etkisine yönelik net bir öngörü bulunmamaktadır. Nüfus artış hızının yüksek olduğu ülkelerde gelir eşitsizliği daha fazla olduğu için analizler sonucunda $\beta_{3 i}>0$ çıkması beklenmektedir.

\subsection{Yöntem}

Bu çalışmada serilerin durağanlıkları Levin, Lin ve Chu (2002, LLC), Im, Pesaran ve Shin (2003, IPS), Maddala ve Wu (1999), Fisher ADF ve Fisher PP panel birim kök testleri ile sınanmıştır. Panel regresyon analizinde hangi yöntemin kullanılacağına Hausman (1978) testi ile karar verilmiştir. Seriler arasındaki 
nedensellik ilişkiler Dumitrescu ve Hurlin (2012) panel nedensellik testi ile incelenmiştir. Çalışmada, 36 OECD ülkesinin 1996-2018 dönemine ait verileri 2020 yılı içerisinde toplanmıştır; çalışma için Etik Kurul İzin Belgesi gerekmemektedir.

\subsection{Panel Birim Kök Testleri}

Panel birim kök testlerinde; serinin cari dönemdeki değerinin, bir önceki dönemdeki değerinden etkilenme derecesine bakılmaktadır çalışılır (Gujarati ve Porter, 2012, s. 744). Bu amaçla aşağıdaki denklem kullanılır:

$y_{i t}=\rho_{i} y_{i t-1}+\delta_{i} X_{i t}+\epsilon_{i t}$

Burada $i=1,2, \ldots, N$ yatay kesitleri (bu çagujatalışma için bölgeleri), $t=$ $1,2, \ldots, T$ zaman boyutunu, $X_{i t}$; dışsal değişkenleri, $\rho_{i}$; otoregresif birim kök parametresini ve $\epsilon_{i t}$; beyaz gürültü sürecine sahip (ekonometrik açıdan sorunsuz) hata terimleri serisini ifade etmektedir. Denklem (3)'te birim kök parametresi $\rho_{i}=1$ olduğunda, seri durağan olmamaktadır. Bu tür serilerle yapılacak analizlerde sahte (Spurious) regresyon sorunu ile karşlaşılabilmektedir (Granger ve Newbold, 1974). Denklem (3)'te genellikle otokorelasyon sorunu ile karşılaşılabildiği için bu model aşağıdaki şekilde genişletilmektedir:

$y_{i t}=\rho_{i} y_{i t-1}+\sum_{j=1}^{m} \beta_{i j} \Delta Y_{i t-j}+\delta_{i} X_{i t}+\epsilon_{i t}$

Bu çalışmada serilerin durağanlıkları LLC, IPS, Fisher ADF ve Fisher PP panel birim kök testleri ile incelenmiştir. LLC testinde kullanılan test istatistiği:

$\Delta y_{i t}=\rho y_{i t-1}+\sum_{j=1}^{m} \beta_{i j} \Delta y_{i t-j}+\delta_{i} X_{i t}+e_{i t}$

denklemi ile elde edilmektedir. Denklem (5)'te yer alan $m$; optimum gecikme uzunluğu olup, Schwarz Bilgi Kriteri (Schwarz Information Criterion: SBC) veya Akaike Bilgi Kriteri (Akaike Information Criterion: AIC) yardımiyla belirlenebilmektedir. LLC testinde, birim kök parametresi $(\rho)^{\prime}$ nun bütün yatay kestiler (bu çalışmada firmalar) için aynı olduğu kabul edilmektedir. Im, Pesaran ve Shin (2003), bu varsayımın her zaman gerçekçi olmayabileceğini ifade ederek, birim kök 
sınamasında, birim kök parametresinin yatay kestiler arasında farklı olmasına izin veren Denklem (6)'nın kullanılmasının gerektiğini belirtmişlerdir:

$\Delta y_{i t}=\rho_{i} y_{i t-1}+\sum_{j=1}^{m} \Delta y_{i t-j}+\delta_{i} X_{i t}+e_{i t}$

Denklem (6)'da, Denklem (5)'ten farklı olarak $\rho_{i}$ kullanıldı̆̆ına dikkat etmek gerekir. Böylece her bir yatay kesit için bireysel (individual) birim kök parametreleri elde edilebilmektedir. Maddala ve Wu (1999) tarafından geliştirilen Fisher ADF ve Fisher PP yöntemlerinde test istatistiği Denklem (7) yardımıyla elde edilir:

$Z=\frac{1}{\sqrt{N}} \sum_{i=1}^{N} \Phi^{-1}\left(y_{i}\right) \rightarrow N(0,1)$

$\mathrm{Bu}$ iki yöntemin farkı; her bir yatay kesit için hesaplanan birim kök test istatistiklerinin olasılık değerlerinin hesaplanma biçiminden kaynaklanmaktadır. $\mathrm{Bu}$ çalışmada serilerin durağanlıkları LLC, IPS, Fisher ADF ve Fisher PP panel birim kök testleri ile sınanmış ve elde edilen sonuçlar Tablo 6' da sunulmuştur.

Tablo 6. Panel Birim Kök Testlerinin Sonuçları

\begin{tabular}{cllllllll}
\hline & \multicolumn{2}{c}{ LLC } & \multicolumn{2}{c}{ IPS } & \multicolumn{2}{c}{ Fisher ADF } & \multicolumn{2}{c}{ Fisher PP } \\
\cline { 2 - 9 } & Sabitli & $\begin{array}{l}\text { Sabitli ve } \\
\text { Trendli }\end{array}$ & Sabitli & $\begin{array}{l}\text { Sabitli ve } \\
\text { Trendli }\end{array}$ & Sabitli & $\begin{array}{l}\text { Sabitli ve } \\
\text { Trendli }\end{array}$ & Sabitli & $\begin{array}{l}\text { Sabitli ve } \\
\text { Trendli }\end{array}$ \\
\hline \multirow{2}{*}{ GINI } & $-3.54^{* * *}$ & $-3.77^{* * *}$ & -0.93 & $-2.92^{* * *}$ & $94.88^{* *}$ & $106.11^{* * *}$ & $66.01(0.67)$ & 52.2 \\
& $(0.00)$ & $(0.00)$ & $(0.17)$ & $(0.00)$ & $(0.03)$ & $(0.00)$ & & $(0.96)$ \\
\hline \multirow{2}{*}{ TR } & $-3.64^{* * *}$ & -1.16 & $-2.04^{* *}$ & $-1.85^{* *}$ & $90.40^{*}$ & $103.87^{* * *}$ & $96.50^{* *}$ & 71.04 \\
& $(0.00)$ & $(0.12)$ & $(0.02)$ & $(0.00)$ & $(0.07)$ & $(0.00)$ & $(0.02)$ & $(0.50)$ \\
\hline \multirow{2}{*}{ G } & $-13.55^{* * *}$ & $-11.28^{* * *}$ & $-12.11^{* * *}$ & $-9.11^{* * *}$ & $278.65^{* * *}$ & $206.02^{* * *}$ & $289.91^{* * *}$ & $266.60^{* * *}$ \\
& $(0.00)$ & $(0.00)$ & $(0.00)$ & $(0.00)$ & $(0.00)$ & $(0.00)$ & $(0.00)$ & $(0.00)$ \\
\hline \multirow{2}{*}{ POP } & -0.84 & -0.44 & $-4.02^{* * *}$ & $-5.47^{* * *}$ & $139.54^{* * *}$ & $164.04^{* * *}$ & $94.44^{* *}$ & 79.23 \\
& $(0.19)$ & $(0.32)$ & $(0.00)$ & $(0.00)$ & $(0.00)$ & $(0.00)$ & $(0.03)$ & $(0.26)$ \\
\hline
\end{tabular}

Not: Optimum gecikme uzunlukları Akaike Bilgi Kriteri kullanılarak, Eviews 10 programı tarafından otomatik olarak belirlenmiştir. ${ }^{* * *}$, ** ve *; sırasıyla \%1, \%5 ve \%10 anlamlılık düzeyinde durağanlığı ifade etmektedir.

Tablo 6'daki bulgular değerlendirilirken; bu 8 yönteme göre en fazla önerilen sonuç kabul edilmiştir. Buna göre; tüm seriler düzey değerlerinde durağan, yani I(0)'dır. Bu durumda, Granger ve Newbold (1974)'e göre bu serilerin düzey değerleri kullanılarak yapışacak analizlerde sahte regresyon problemiyle karşılaşılabilecektir. Bu sorunu önleyebilmek için, Engle ve Granger (1987), öncelikle eşbütünleşme testi 
yapılmasının gerektiğini, seriler eşbütünleşik çıktıklarında sahte regresyon problemi ile karşılaşılmayacağını ifade etmiştir.

\subsection{Panel Regresyon Analizleri}

Seriler düzey değerlerinde durağan olduğunda, panel regresyon analizi 3 farklı yöntemle yapılabilmektedir: Havuzlanmış Panel Veri Analizi, Sabit Etkiler Modeli ve Rassal Etkiler Modeli. Panel veri analizlerinde kullanılan genel denklem yapısı aşağıdaki gibidir:

$Y_{i t}=\beta_{0}+\beta_{1} X_{1 i t}+\beta_{2} X_{2 i t}+. .+\beta_{k} X_{k i t}+\mu_{t}+v_{i}+\varepsilon_{i t}$

Burada; $i=1, \ldots, N$ yatay kesitleri (bu çalışmada firmaları), $t=1, \ldots, T$ panel veri modelinin zaman boyutunu göstermektedir. $Y$; bağımlı (açıklanan) değişkeni, $X_{1}, X_{2}, \ldots, X_{k}$; bağımsız (açıklayıc) değişkenleri ifade etmektedir. $\mu_{t}$ ve $v_{i}$; sırasıyla zaman ve yatay kesit etkilerini temsil etmektedir. $\varepsilon_{i t}$ ise; ortalaması sıfır, varyansı sabit (yani ekonometrik olarak sorunsuz), alacağı değerler stokastik olarak belirlenen hata terimleri serisidir (Baltagi, 1995, s. 13).

Havuzlanmış panel veri analizi yönteminde; zaman ve yatay kesit etkilerinin olmadığ1 varsayılmaktadır. Bu durumda $\mu_{t}$ ve $v_{i}$ parametreleri modelden dışlanarak, Denklem (9) yardımıyla tahminler yapılmaktadır (Greene, 2002, s. 287-293).

$Y_{i t}=\beta_{0}+\beta_{1} X_{1 i t}+\beta_{2} X_{2 i t}+. .+\beta_{k} X_{k i t}+\varepsilon_{i t}$

Havuzlanmış panel veri analizi yöntemi, bireysel ve zaman etkilerini dışlaması yönüyle bir eksikliğe sahip olmakla birlikte, tutarlı sonuçlar ürettiği için literatürde geniş bir uygulama alanına sahip olmuştur.

Denklem (10)'da yer alan zaman etkilerinin ve yatay kesit etkilerinin modelden tamamen dışlanması yerine, sabit olduğunun kabul edilmesiyle, Sabit Etkiler Modeline ulaşılmıştır. Bu yöntemde; yatay kesit ve zaman etkilerinin, var olabileceği öngörülmekte ve bu etkilerin, modelin sabit teriminde ortaya çıkacağ1 kabul edilmektedir. Yöntemin isminde geçen sabit ifadesi; katsayıların, yatay kesit birimlerine göre değişebileceğini ancak zamana göre sabit olduğunu ifade etmektedir. $\mathrm{Bu}$ yöntemde; gözlemlenemeyen bireysel etkilerin, modelde yer alan açıklayıcı 
değişkenlerle ilişkili olduğu kabul edilmektedir. Sabit Etkiler Yönteminde kullanılan ekonometrik model:

$Y_{i t}=\beta_{0}+\beta_{1} X_{1 i t}+\beta_{2} X_{2 i t}+. .+\beta_{k} X_{k i t}+v_{i}+\varepsilon_{i t}$

şeklindedir. Bu modelde sabit terimler arasındaki farklılıklar, yatay kesit birimlerine özgü karakteristikleri temsil eden kukla değişkenler yardımıyla analize dâhil edilmektedir (Wooldridge, 2013, s. 493).

Denklem (11)'de zaman etkilerinin ve yatay kesit etkilerinin zaman içinde ve yatay kesitler arasında değişmekte olduğunun kabul edildiği Rassal Etkiler Yönteminde; yatay kesitlerde (firmalarda) veya zaman içinde meydana gelen değişimler, hata teriminin bir bileşeni olarak modele dâhil edilmektedir. Bu yolla, sabit etkiler yönteminde modele çok sayıda kukla değişken eklenmesine bağlı olarak yaşanan serbestlik derecesi kaybı ortadan kaldırılmaktadır. Bu çerçevede Rassal Etkiler Yönteminde kullanılan model;

$Y_{i t}=\beta_{0}+\beta_{1} X_{1 i t}+\beta_{2} X_{2 i t}+. .+\beta_{k} X_{k i t}+\zeta_{i t}$

biçimindedir. Burada $\zeta_{i t}=v_{i}+\varepsilon_{i t}$ şeklindedir. Burada $v_{i}{ }^{\prime}$ lerin $\varepsilon_{i t}$ 'lerden bağımsız olduğu varsayılmaktadır (Baltagi, 1995, s. 13).

Panel regresyon analizinde bu yöntemlerden hangisinin seçileceğine literatürde genellikle Hausman (1978) Testi ile karar verilmektedir. Temelde bir içsellik sınaması olan Hausman (1978) Testi, bağımsız değişkenler $\left(X_{k}\right)$ ile modelin hata terimi $\left(\varepsilon_{i t}\right)$ arasında bir ilişkinin var olup olmadığını sınamaktadır. Ama bu işlemi yaparken de Sabit Etkiler Yöntemi ile Rassal Etkiler Yöntemi arasında seçim yapılabilmesine olanak tanımaktadır. Hausman testinde sinanan hipotezler:

$$
\begin{aligned}
& H_{0}: E\left(\varepsilon_{i} \mid X_{k}\right)=0 \quad \text { Yatay kesit ve zaman etkileri tesadüfidir, } \\
& H_{1}: E\left(\varepsilon_{i} \mid X_{k}\right) \neq 0 \quad \text { Yatay kesit ve zaman etkileri sabittir, }
\end{aligned}
$$

biçimindedir. Hausman testinin $H_{0}$ hipotezi; "gözlemlenemeyen etkilerin, modeldeki diğer açıklayıcı değişkenlerle bir ilgisinin olmadığıı, yani dışsal olduğunu" öne sürmektedir. Bu testte $H_{0}$ hipotezi reddedildiğinde etkilerin sabit olduğuna, $H_{0}$ hipotezi reddedilemediğinde ise etkilerin rassal olduğuna karar verilmektedir (Greene, 2002, s. 
80). Çalışmada her bir model için Hausman Testi uygulanmış ve elde edilen sonuçlar Tablo 7'de sunulmuştur.

Tablo 7. Hausman Testi Sonucu

\begin{tabular}{lcc}
\hline & Ki-Kare Test İstatistiği & Olasılık Değeri \\
\hline Yatay Kesit Etkileri Rassal & 0.00 & 1.00 \\
\hline Zaman Etkileri Rassal & 15.17 & 0.00 \\
\hline Yatay Kesit ve Zaman Etkileri Rassal & 11.98 & 0.00 \\
\hline
\end{tabular}

Tablo 7'den elde edilen sonuçlara göre etkilerin ne tam olarak rassal ne de tam olarak sabit olmadığ1 görülmektedir. Bu şekilde Hausman Testi ile net bir sonuca ulaşılamadığında ya da araştırmacı tarafından bütün alternatifler değerlendirilmek istendiğinde, üç yöntem bir arada da kullanılabilmektedir. Bu çalışmada da panel regresyon analizi üç yöntemle de yapılmış ve elde edilen sonuçlar Tablo 8'de sunulmuştur.

Tablo 8. Panel Regresyon Analizi Sonuçları

\begin{tabular}{|c|c|c|c|}
\hline & $\begin{array}{c}\text { Havuzlanmiş Panel } \\
\text { Veri Analizi }\end{array}$ & $\begin{array}{l}\text { Sabit Etkiler } \\
\text { Yöntemi }\end{array}$ & Rassal Etkiler Yöntemi \\
\hline$T R$ & $\begin{array}{l}-0.61^{* * *} \\
(0.00)\end{array}$ & $\begin{array}{l}-0.03 \\
(0.14)\end{array}$ & $\begin{array}{l}0.02 \\
(0.25)\end{array}$ \\
\hline$G$ & $\begin{array}{l}-0.23^{* * *} \\
(0.00)\end{array}$ & $\begin{array}{l}0.0003 \\
(0.98)\end{array}$ & $\begin{array}{l}-0.003 \\
(0.83)\end{array}$ \\
\hline POP & $\begin{array}{l}0.63^{* * *} \\
(0.00)\end{array}$ & $\begin{array}{l}-0.25^{* *} \\
(0.01)\end{array}$ & $\begin{array}{l}-0.12 \\
(0.21)\end{array}$ \\
\hline$K_{2008}$ & $\begin{array}{l}-0.94 \\
(0.12)\end{array}$ & $\begin{array}{l}0.40 \\
(0.57)\end{array}$ & $\begin{array}{l}0.06 \\
(0.63)\end{array}$ \\
\hline Sabit Değer & $\begin{array}{l}42.92^{* * *} \\
(0.00)\end{array}$ & $\begin{array}{l}31.60^{* * *} \\
(0.00)\end{array}$ & $\begin{array}{l}30.49^{* * *} \\
(0.00\end{array}$ \\
\hline$R^{2}$ & 0.40 & 0.97 & 0.005 \\
\hline $\bar{R}^{2}$ & 0.40 & 0.97 & 0.0008 \\
\hline F Istatistiğ $i$ & $\begin{array}{l}140.56 \\
(0.00)\end{array}$ & $\begin{array}{l}452.46 \\
(0.00)\end{array}$ & $\begin{array}{l}1.17 \\
(0.31)\end{array}$ \\
\hline$D W$ & 2.01 & 1.99 & 1.98 \\
\hline LR & $\begin{array}{l}581.31 \\
(0.17)\end{array}$ & $\begin{array}{l}381.37 \\
(0.22)\end{array}$ & $\begin{array}{l}122.27 \\
(0.42)\end{array}$ \\
\hline
\end{tabular}

Tablo 8'deki sonuçlar arasında en yorumlanabilir olanları, havuzlanmış panel veri analizi yöntemiyle elde edilen bulgulardır. Buna göre; OECD ülkelerinde, 19962018 döneminde hane halkına yönelik gerçekleştirilen transfer ödemeleri gelir 
dağılımı eşitsizliğini azaltmıştır. Bu sonuç, çalışmamızın odaklandığ1 temel soru noktasında oldukça önemlidir. Ekonomik büyümedeki artışlar da gelir dağılımı eşitsizliğini azaltıcı yönde etki etmiştir. $\mathrm{Bu}$ da elde edilen gelirin adil biçimde bölüşüldüğünü göstermektedir. Nüfus artışı ise gelir dağılımı dengesizliğini artırıcı yönde etki etmiştir. Ama sabit etkiler modelinde bu etkinin azaltıcı yönde olduğu görülmektedir. $\mathrm{Bu}$ nedenle nüfus artışının etkileri konusunda kesin bir karar verilememiştir. 2008 Küresel Ekonomik Krizi, havuzlanmıs modelde gelir dağılımı dengesizliğini azaltıcı yönde, ama istatistiksel olarak anlamsız düzeyde etki etmiştir.

Tablonun alt bölümünde yer alan model doğrulama testleri; ilk iki yöntemle yapılan analizlerde modelin açıklama gücünün $\left(R^{2}\right)$ yeterince yüksek, modelde yer alan bağımsız değişkenlerin bağımlı değişkeni anlamlı düzeyde açıkladığını $(F)$, modelde otokorelasyon $(D W)$ ve değişen varyans $(L R)$ sorunlarının olmadığını göstermektedir.

\subsection{Panel Nedensellik Testi}

$\mathrm{Bu}$ çalışmada seriler arasında nedensellik ilişkilerinin varlığı ve yönü; Dumitrescu ve Hurlin (2012) panel nedensellik testi ile incelenmiştir. Bu yöntem; paneli oluşturan yatay kesitlerden (bu çalışmada ülkelerden) bazıları için var olan nedensellik ilişkilerini de belirleyebilmektedir. Yani panelin genelinde nedensellik ilişkisi olmasa bile bazı yatay kesitlerde var olan nedensellik ilişkilerine de ulaşabilmektedir. $X$ ve $Y$ şeklindeki örnek iki seri arasında Dumitrescu ve Hurlin (2012) panel nedensellik testi aşağıdaki denklem sistemi yardımıyla gerçekleştirilebilmektedir:

$$
\begin{aligned}
& Y_{i t}=\alpha_{i}+\sum_{k=1}^{m} \gamma_{i}^{k} Y_{i t-k}+\sum_{k=1}^{m} \beta_{i}^{k} X_{i t-k}+\varepsilon_{i t} \\
& X_{i t}=\theta_{i}+\sum_{k=1}^{m} \delta_{i}^{k} X_{i t-k}+\sum_{k=1}^{m} \aleph_{i}^{k} Y_{i t-k}+\epsilon_{i t}
\end{aligned}
$$

Bu denklemlerde $m$; optimum gecikme uzunluğunu göstermekte olup, Akaike, Schwarz veya diğer bilgi kriterleri yardımıyla belirlenebilmektedir. Denklem (12) ve 
Denklem (13)'de $X^{\prime}$ ten $Y^{\prime}$ ye doğru olan nedensellik ilişkisi test edilmektedir ve bu işlemde kullanılacak hipotezler:

$H_{0}: \beta_{i}^{(k)}=0$ bütün i'leriçin.

Yani, bütün yatay kesitlerde $X^{\prime}$ ten $Y^{\prime}$ ye

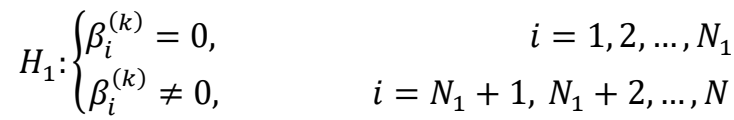

Yani, bazı yatay kesitlerde $X^{\prime}$ ten $Y^{\prime}$ ye doğru bir nedensellik ilișkisi vardır.

$\mathrm{Bu}$ çalışmada nedensellik testinde kullanılacak optimum gecikme uzunluğu belirleme işlemleri sonuçları Tablo 9'da yer almaktadır.

Tablo 9. Model Gecikme Uzunluğu Belirleme

\begin{tabular}{ccccccc}
\hline Lag & LogL & LR & FPE & AIC & SC & HQ \\
\hline 0 & -5277.281 & NA & 3673.101 & 19.56030 & 19.59209 & 19.57273 \\
\hline 1 & -1921.443 & 6649.530 & 0.015592 & 7.190531 & 7.349478 & 7.252695 \\
\hline 2 & -1769.843 & 298.1476 & 0.009436 & 6.688307 & $6.974412^{*}$ & $6.800202^{*}$ \\
\hline 3 & $\mathbf{- 1 7 4 5 . 3 9 7}$ & $\mathbf{4 7 . 7 1 5 1 4}$ & $\mathbf{0 . 0 0 9 1 4 6 *}$ & $\mathbf{6 . 6 5 7 0 2 6}$ & $\mathbf{7 . 0 7 0 2 8 8}$ & $\mathbf{6 . 8 1 8 6 5 1}$ \\
\hline 4 & -1734.260 & 21.57300 & 0.009313 & 6.675036 & 7.215456 & 6.886393 \\
\hline 5 & -1720.652 & 26.15807 & 0.009396 & 6.683895 & 7.351472 & 6.944982 \\
\hline 6 & -1710.609 & 19.15557 & 0.009607 & 6.705959 & 7.500694 & 7.016777 \\
\hline 7 & -1695.918 & $27.80409^{*}$ & 0.009655 & 6.710807 & 7.632699 & 7.071356 \\
\hline 8 & -1687.887 & 15.08021 & 0.009946 & 6.740322 & 7.789372 & 7.150603 \\
\hline
\end{tabular}

Not: LR: Lagrange oran testi, FPE; Son tahmin hatas1, AIC; Akaike bilgi kriteri, SC; Schwarz bilgi kriteri ve HQ; Hannan-Quin bilgi kriteridir.

Tablo 9'daki sonuçlara göre FPE ve AIC temel alındığında optimum gecikme uzunluğu 3'tür. 3 gecikmeli VAR modelinin (VAR(3)) ve bu modele dayanarak yapılacak nedensellik testi sonuçlarının istikrarlı olduğunu gösterebilmek için ters karakteristik polinomal kökler grafiği çizilmiş ve Şekil 2'de sunulmuştur. 


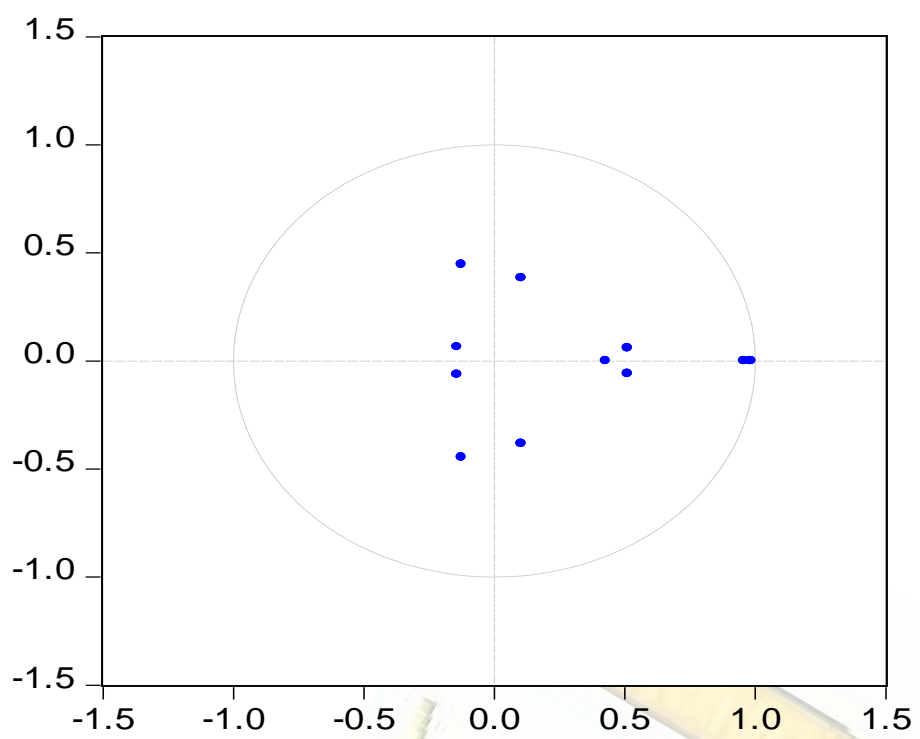

Şekil 2. Ters Karakteristik Polinomal Kökler Grafiği

Şekil 2'de ters karakteristik polinomal kökler birim çemberin içinde kaldığı için 3 gecikme ile gerçekleştirilecek nedensellik analizi sonuçları istikrarlıdır. Çalışmada Dumitrescu ve Hurlin (2012) panel nedensellik testi, 3 gecikme ile yapılmış ve elde edilen sonuçlar Tablo 10' da sunulmuştur.

Tablo 10. Dumitrescu ve Hurlin (2012) Panel Nedensellik Testi Sonuçları

\begin{tabular}{|c|c|c|c|}
\hline $\mathrm{H}_{0}$ Hipotezi & $W$ İstatistiğ $i$ & $\bar{Z}$ İstatistiği & Olasılık Değeri \\
\hline$T R \nRightarrow G I N I$ & $5.29 * * *$ & $2.90 * * *$ & 0.00 \\
\hline$G I N I \nRightarrow T R$ & $6.95^{* * *}$ & $5.65^{* * *}$ & 0.00 \\
\hline$G \nRightarrow G I N I$ & 3.84 & 0.48 & 0.62 \\
\hline$G I N I \nRightarrow G$ & $6.31^{* * *}$ & $4.60^{* * *}$ & 0.00 \\
\hline$P O P \nRightarrow G I N I$ & $4.79 * *$ & $2.07^{* *}$ & 0.03 \\
\hline$G I N I \nRightarrow P O P$ & $4.68^{*}$ & $1.89 *$ & 0.05 \\
\hline$G \nRightarrow T R$ & $5.82^{* * *}$ & $3.78^{* * *}$ & 0.00 \\
\hline$T R \nRightarrow G$ & 4.39 & 1.41 & 0.15 \\
\hline$P O P \nRightarrow T R$ & $4.66^{*}$ & 1.85 & 0.06 \\
\hline$T R \nRightarrow P O P$ & $6.71^{* * *}$ & $5.27^{* * *}$ & 0.00 \\
\hline$P O P \nRightarrow G$ & 4.30 & 1.25 & 0.20 \\
\hline$G \nRightarrow P O P$ & $8.63^{* * *}$ & $8.45^{* * *}$ & 0.00 \\
\hline
\end{tabular}


Tablo 10 'da elde edilen nedensellik ilişkilerinin daha kolay takip edilebilmesi için Şekil 3 hazırlanmıştır.

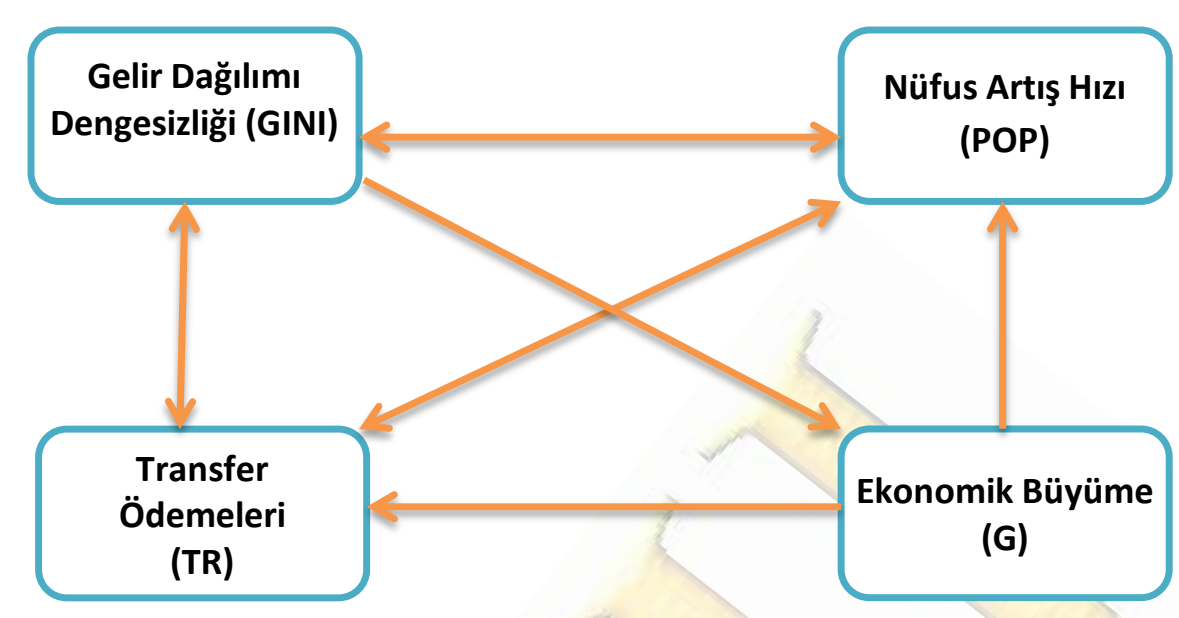

Şekil 3. Nedensellik Testi Sonuçları

Şekil 3'teki sonuçlara göre; OECD ülkelerinde transfer ödemeleri ile gelir dağılımı eşitsizliği arasında karşılıklı nedensellik ilişkisi vardır. Bu ilişki; ülkelerdeki gelir dağılımı dengesizliği arttığında/azaldığında transfer ödemelerinin de arttığını/azaldığını akla getirmektedir. Nitekim Covid-19 sürecinde de başta ABD ve Kanada olmak üzere gelişmiş ülkeler, aylık geliri belirli bir seviyenin altında olan yurttaşlarına karşılıksız para vermişlerdir (transfer ödemesi yapmışlardır). Gelir eşitsizliği ile nüfus artış hızı arasındaki iki yönlü nedensellik ilişkisi; nüfus artış hızı yüksek olan ülkelerde gelir dağılımı dengesizliğinin de yüksek olduğu ön savını destekler niteliktedir. Nüfus artış hızı ile transfer ödemeleri arasındaki karşılıklı nedensellik ilişkisi de özellikle gelişmiş ülkelerde uygulanan çocuk başına devlet yardımı türü ödemeleri akla getirmektedir. Ekonomik büyümeden transfer ödemelerine doğru olan nedensellik ilişkisi; geliri artan ülkelerin yurttaşlarına daha fazla yardım yapabildiklerini düşündürmektedir. Gelir eşitsizliğinden ekonomik büyümeye doğru olan nedensellik ilişkisi ise; ülkelerde gelir dağılımı dengesizliği azaldığında, bireylerin emeklerinin karşılığını daha rahat aldıklarını ve bu sayede daha verimli çalışarak, ülkelerinin ekonomik büyümelerine olumlu yönde katkı yaptıklarını düşündürmektedir. 


\section{SONUÇ}

Bu çalışmada sosyal amaçlı transfer harcamalarının gelir dağılımına etkisi, 36 OECD ülkesinin 1996-2018 dönemi verileri kullanılarak analiz edilmiştir. Çalışmada bağımlı değişken olarak; GINI katsayısı, bağımsız değişken olarak hane halkına yönelik transfer ödemelerinin milli gelire oranı verileri kullanılmıştır. Ayrıca ekonomik büyüme oranı ve nüfus artış hızı verileri de kontrol değişkenleri olarak analize dâhil edilmiştir. Son olarak; analiz döneminde yer alan ve genel olarak bütün ülkeleri etkileyen 2008 Küresel Ekonomik Krizi de kukla değişken ile analize dâhil edilmiştir. Çalışmanın sonucunda elde edilen bulgulara göre; OECD ülkelerinde, 19962018 döneminde hane halkına yönelik gerçekleştirilen transfer ödemeleri gelir dağılımı eşitsizliğini azaltmıştır. Bu sonuç, çalışmamızın odaklandığı temel soru noktasında oldukça önemlidir. $\mathrm{O}$ halde ülkelerin, yurttaşları arasındaki gelir dengesizliğini azaltabilmeleri için transfer ödemelerini artırarak yapmaya devam etmelerinde yarar vardır. Ekonomik büyümedeki artışlar da gelir dağılımı eşitsizliğini azaltıcı yönde etki etmiştir. Bu da elde edilen gelirin adil biçimde bölüşüldüğünü akla getirmektedir. Nüfus artışı ise gelir dağılımı dengesizliğini artırıcı yönde etki etmiştir. Ama sabit etkiler modelinde bu etkinin azaltıcı yönde olduğu görülmektedir. Bu nedenle nüfus artışının etkileri konusunda kesin bir karar verilememiştir. 2008 Küresel Ekonomik Krizi'nin, havuzlanmış modelde gelir dağılımı dengesizliğini azaltıcı yönde, ama istatistiksel olarak anlamsız düzeyde etki ettiği belirlenmiştir.

Seriler arasında nedensellik ilişkilerinin varlığı ve yönü; Dumitrescu ve Hurlin (2012) panel nedensellik testi ile incelenmiştir. Bu test sonucunda; OECD ülkelerinde transfer ödemeleri ile gelir dağılımı eşitsizliği arasında karşılıklı nedensellik ilişkisi bulunmuştur. Bu ilişki; ülkelerdeki gelir dağılımı dengesizliği arttığında/azaldığında transfer ödemelerinin de arttığını/azaldığını akla getirmektedir. Nitekim Covid-19 sürecinde de başta $A B D$ ve Kanada olmak üzere gelişmiş ülkeler, aylık geliri belirli bir seviyenin altında olan yurttaşlarına karşılıksız para vermişlerdir (transfer ödemesi yapmışlardır). Gelir eşitsizliği ile nüfus artış hızı arasındaki iki yönlü nedensellik ilişkisi; nüfus artış hızı yüksek olan ülkelerde gelir dağılımı dengesizliğinin de yüksek olduğu önsavını destekler niteliktedir. Nüfus artış hızı ile transfer ödemeleri arasındaki karşılıklı nedensellik ilişkisi de özellikle gelişmiş ülkelerde uygulanan 
çocuk başına devlet yardımı türü ödemeleri akla getirmektedir. Ekonomik büyümeden transfer ödemelerine doğru olan nedensellik ilişkisi; geliri artan ülkelerin yurttaşlarına daha fazla yardım yapabildiklerini düşündürmektedir. Gelir eşitsizliğinden ekonomik büyümeye doğru olan nedensellik ilişkisi ise; ülkelerde gelir dağılımı dengesizliği azaldığında, bireylerin emeklerinin karşılığını daha rahat aldıklarını ve bu sayede daha verimli çalışarak, ülkelerinin ekonomik büyümelerine olumlu yönde katkı yaptıklarını düşündürmektedir. Bu çalışmadan elde edilen bulgulara dayanarak; ülkelerin yurttaşlarına yaptıkları transfer ödemelerinin, gelir dağılımı dengesizliğini azaltıcı yönde etkilerinin olduğu, bu nedenle ülkelerin kendi imkânları ölçüsünde bu tür yardımlara devam etmelerinin yararlı olacağı söylenebilir. Ama bu noktada bir kısım yurttaşların hazıra alışması ve çalışmadan, devlet yardımlarıyla geçinmeyi adet edinmesinin de önüne geçilmesinin gereği ve kişilere "balık vermek yerine, balık tutmayı öğretmek" ve onları çalışan ve üreten bireyler haline getirmenin önemi de göz ardı edilmemelidir. Bu tür sosyal yardımların her zaman suiistimale açık olduğu, gerçekte ihtiyaç sahibi olmayan kişilerinde bu yardımlardan faydalanmaya çalışabileceği ve bu durumun Yunanistan' da olduğu gibi ekonomiyi zor duruma düşürebileceği gerçeği de unutulmamalı ve gerekli önlemler kamu eliyle alınmalıdır. Ekonomik büyüme yoluyla elde edilen gelirin tüm yurttaşlar arasında hakça bölüşülmesi büyük önem taşımaktadır. Bu noktada devletlerin, özel sektörde çalışan kişilerin maaş ve diğer özlük haklarını düzenleyici ve denetleyici olma işlevlerini, etkin bir şekilde yerine getirmeleri oldukça önemlidir. Dengesiz göç alımı ile ülke nüfuslarının anormal biçimde artması, ülkede yerleşik kişilerin refahların azaltabilmektedir. Bu nedenle, devletlerin göçmen kabulü politikalarını, sahip oldukları ekonomik güçleriyle ve istihdam edebilecekleri kişi sayısıyla uyumlu biçimde sürdürmelerinde yarar vardır.

Transfer ödemeleri, sosyal devlet olmanın doğal bir gereği olup, ihtiyacı olan yurttaşlarına devletler tarafından yapılan her türlü karşılıksız yardım, burs ödemesi, ayni yardımlar, emekli dul ve yetimlere ve bu kişilerin yakınlarına yapılan ödemeler, engelli bireylere ve bu bireylere bakan yakınlarına yapılan ödemeler, işsizlik maaşları ile emekli maaşlarından oluşmaktadır. Burada, özellikle ihtiyaç sahibi kişilere yapılan nakdi yardımların bu kişileri yoksulluk çıkmazından çıkarıp çıkarmadığı büyük önem 
taşımaktadır. Eğer, bu yardımlar, düşük gelirli kişiler ile yüksek gelirli kişiler arasındaki farkın kapanmasına yardımcı oluyorsa, sosyal barışın sağlanması anlamında gerçek amacına ulaşıyor demektir. Aksi takdirde, Arap Baharı olaylarında olduğu gibi sosyal patlamaların yaşanması olgusu yüksek ihtimaldir. 


\section{KAYNAKÇA}

Afonso, A., Schuknecht, L. ve Tanzi, V. (2010). Income Distribution Determinants and Public Spending Efficiency. Journal of Economic Inequality, 8(3), 367-389.

Alesina, A. ve Rodrik, D. (1994). Distributive Politics and Economic Growth, Quarterly Journal of Economics, Vol. 109, No. 2 (May, 1994), s. 465-490.

Baltagi, B. H. (1995). Econometric Analysis of Panel Data, John Wiley\&Sons Ltd. England.

Bastagli, F., Coady, D. ve Gupta, S. (2012). Income inequality and fiscal policy, International Monetary Fund Staff Discussion Note, No. SDN/12/08R.

Caminada, K., Goudswaard, K. ve Wang, C. (2012). Disentangling Income Inequality and the Redistributive Effect of Taxes and Transfers in 20 LIS Countries Over Time, LIS Working Paper Series, No: 581 , s.s. $1-47$.

Chu, K., Davoodi, H. ve Gupta, S. (2000). Income Distribution and Tax, and Government Social Spending Policies in Developing Countries. (No. 214), World Institute for Development Economics Research (UNU-WIDER), Erişim Adresi https://www.wider.unu.edu/sites/default/files/wp214.pdf. Cimoli, M., Neto, A. M., Porcile, G. ve Sossdorf, F. (2017). Productivity, Social Expenditure and Income Distribution in Latin America, Brazilian Journal of Political Economy, 37(4), s. 660-679.

Çalışkan, Ş. (2010). Türkiye' de Gelir Eşitsizliği ve Yoksulluk, Sosyal Siyaset Konferanslan Dergisi, (59), s. 89-132.

D’Agostino, G., Pieroni, L. ve Procidano, I. (2016). Revisiting the Relationship Between Welfare Spending and Income Inequality in OECD Countries. Munich Personal RePEc Archive, s. 1-27.

DPT (2020). Gelir Dağılımı ve Politikaları 7.BYKP, Erişim Adresi http://ekutup.dpt.gov.tr/plan/plan7.pdf.

Dumitrescu, E. I. ve Hurlin, C. (2012). Testing for Granger Non-Causality in Heterogeneous Panels. Economic Modelling, 29(4), s. 1450-1460.

Engle, F. E. ve Granger C. W. J. (1987). Co-integration and Error Correction: Representation and Testing. Econometrica, (55), s. 251-276.

Eroğlu, N., Altaş, D., Turgut, Ü. N. ve Ulu, M. İ. (2017). OECD Ülkelerinde Sosyal Yardım Harcamalarının Gelir Dağılımına Etkisi: Panel Veri Analizi, Uluslararası Ekonomik Araştırmalar Dergisi, 3(3), s. 335-354.

Frederick, S. (2019). The Standardized World Income Inequality Database, Erişim Adresihttps:// dataverse.harvard.edu/dataset.xhtml?persistentId=doi:10.7910/DVN/LM4OWF. 
Granger, C. W. J. ve Newbold, P. (1974). Spurious Regressions in Econometrics. Journal of Econometrics, 2(2), s. 111-120.

Greene, W. H. (2002). Econometric Analysis. (Fifth Edition). Prentice Hall, New Jersey.

Gujarati, D. N. ve Porter, D. C. (2012). Temel Ekonometri (Beşinci Basımdan Çeviri), Çevirenler: Ümit Şenesen ve Gülay Güllük Şenesen. Literatür Yayınevi, İstanbul.

Gustafsson, B. ve Johansson, M. (1999). In search of smoking guns: What makes income inequality vary over time in different countries?. American Sociological Review, 64 (4): 585-605.

Hazman, G. G. (2011). Türkiye' de Gelir Dağılımında Adalet ve Sosyal Güvenlik Harcamaları Arasındaki Nedensellik İlişkisi, Süleyman Demirel Üniversitesi İktisadi ve İdari Bilimler Fakültesi Dergisi, 16(1), s. 205216.

Heald, D. ve McLeod, A. (2002). Constitutional Law, The Laws of Scotland: Stair Memorial Encyclopaedia, Edinburgh: Butterworths.

Holzner, M. (2011). Inequality, Growth and Public Spending in Central, East and Southeast Europe, ECINEQ WP, s. 1-25.

Huber, E., Pribble, J. ve Stephens, J. D. (2004). "Social Spending and Inequality in Latin America and the Caribbean" In Paper Delivered at The Meetings of The Society for The Advancement of Socio-Economics, Washington. DC. July.

Im, K. S., Pesaran, M. H. ve Shin, Y. (2003). Testing for Unit Roots in Heterogenous Panels. Journal of Econometrics, 115, 53-74.

IMF (2001). A Manual on Government Finance Statistics, ErişimAdresi www.imf.org/external/pubs/ft/gfs/manual/pdf/all.pdf.

İlgün, M. F. (2015). Kamu Sosyal Harcamalarının Gelir Dağılımı Üzerindeki Etkisi: OECD Ülkelerine Yönelik Panel Veri Analizi, Dokuz Eylül Üniversitesi Sosyal Bilimler Enstitüsü Dergisi, 17(4), s. 493-516.

Karaman, B. ve Özçalık, M. (2007). Türkiye'de gelir dağılımı eşitsizliğinin bir sonucu, Yönetim ve Ekonomi Dergisi, Cilt:14. Sayı:1. s. 25-41.

Keane, M.P. ve Prasad, E.S. (2000). Inequality, Transfers and Growth: New Evidence from the Economic Transition in Poland, The Review of Economics and Statistics, 84(2), s. 324-341.

Kozuharov, S., ve Petkovski, V. (2018). The Impact of Social Transfers on Inequality Measured By Gini Index : The Example of Macedonia, UTMS Journal of Economics, 9(1), s. 49-61.

Levin, A., Lin, C. F. ve Chu, C. S. J. (2002). Unit Root Tests in Panel Data: Asymptotic and Finite-Sample Properties. Journal of Econometrics, 108, s. 1-24.

Li, H., Xie, D. ve Zou, H. (2000). Dynamics of Income Distributio, Canadian Journal of Economics, Vol. 33, No. 4, 2000, s. 937-961. 
Maddala, G. S. ve Wu, S. (1999). A Comparative Study of UnitRoot Tests with Panel Data and a New Simple Test, Oxford Bulletin of Economics and Statistics, 61, s. 631-652.

Martínez-Vazquez, J., Vulovic, V. ve Dodson, B. M. (2014). The Impact of Tax and Expenditure Policies on Income Disttribution: Evidence from a Large Panel of Countries, Hacienda Pública Española/Review of Public Economics, 200-(4/2012): s. 95-130.

Niehues, J. (2010). Social Spending Generosity and Income Inequality: A Dynamic Panel Approach, Discussion Paper Series, IZA (No. 5178).

OECD (2020a). Income inequality. Erişim Adresi https://data.oecd.org/inequality/incomeinequality.htm.

OECD (2020b). Social Expenditure-Aggregated Data. Erişim Adresi https://stats.oecd.org/Index.aspx?DataSetCode=SOCX_AGG.

Öztürk, N. (2009). İktisatta bölüşüm (1.bs.), Kuram-Politika, Palme Yayıncılık, Ankara.

Öztürk, N. (2017). Gelir dağılımının iktisadi analizi (1.bs.), Ekin Yayınevi, Bursa.

Persson T. ve Tabellini, G. (1994). The American Economic Review, Vol. 84, No. 3 (Jun., 1994), s. 600-621.

Pınar, A. (2019). Maliye Politikası Teori ve Uygulama. 10. Baskı, Ankara: Turhan Yayınevi.

Samuels, P. ve Gilchrist, M. (2014). Pearson Correlation, Statsutor, Community Project. Encouraging Academics to Share Statistics Support Resources.

Schwabish, J., Smeeding, T. ve Osberg, L. (2004). Income Distribution and Social Expenditures: A Crossnational Perspective, Luxemburg Income Study, (LIS) Working Papers Series. No: 350, October 2004, S. $5-23$.

Sylwester, K. (2002). Can Education Expenditures Reduce Income Inequality?. Economics of Education Review, Vol. 21, 2002, s. 43-52.

Ulu, M. İ. (2018). The effect of government social spending on income inequality in oecd: a panel data analysis, International Journal of Economics, Politics, Humanities E Social Sciences, 1 (3), s. 184-202.

Ürper, T. D. (2018). Kamu Harcamalarının Gelir Dağılımı Üzerindeki Etkisi: Türkiye Örneği, Hacettepe Üniversitesi, Sosyal Bilimler Enstitüsü, Maliye Anabilim Dalı, Yüksek Lisans Tezi.

Wang, C, Caminada, K. ve Goudswaard, K. (2012). The Redistributive Effect of Social Transfer Programmes and Taxes: A Decomposition Across Countries, International Social Security Review 65(3), s. $27-48$.

Weede, E. (1997). Income inequality, democracy and growth reconsidered. European Journal of Political Economy, 13 (4), s. 751-764. 
Woo, J., Bova E., Kinda T. ve Zhang, S. (2013). Distributional Consequences of Fiscal Consolidation and The Role of Fiscal Policy: What Do The Data Say?, IMF Working Paper, No. 13-195,

Wooldridge, J. M. (2013). Ekonometriye Giriş. (4. Basımdan Çeviri). (Çeviren: Ebru Çağlayan), Nobel Akademik Yayıncılık, İstanbul.

World Bank (2020a). GDP growth (annual \%). Erişim Adresi https://data.worldbank.org/indicator/NY.GDP.MKTP.KD.ZG?view=chart,

World Bank (2020b). Population growth (annual \%). Erişim Adresi https:/ / data.worldbank.org/indicator/SP.POP.GROW?view=chart.

Yardımcıoğlu, F. ve Yayla, Y. E. (2020). Sosyal Harcamaların Gelir Dağılımı Üzerindeki Etkisi: Orta ve Doğu Avrupa Ülkeleri Örneği. Gümrük Ticaret Dergisi,7(19),s.34-48. 